\title{
Chapter 3 \\ Comparing Inequalities in the Labour Market from a Segmentation Perspective
}

\author{
Pedro López-Roldán, Renata Semenza, and Agustín Salvia
}

\begin{abstract}
The purpose of this chapter is to carry out a comparative analysis of labour markets in Europe and Latin America from the perspective of segmentation in order to explain the processes of social inequality that arise in the workplace, in light of recent trends in global socio-economic changes. The chapter proposes two main objectives. The first is to perform a comparative descriptive analysis of the main features of labour markets among 60 European and Latin American countries. The second objective is to propose a model of comparative analysis of labour inequality from the theoretical perspective of the segmentation of the labour market and structural heterogeneity. We will focus our analysis by selecting two countries, Spain and Argentina, which both underwent a late development of capitalism. The following general hypothesis is formulated: Spain and Argentina, having clearly differentiated features in economic structure, level of development, institutional frameworks and socio-historical processes, show common dynamics in the structuring of the capitalist labour market between a primary and secondary segment. Using equivalent databases on the workforce a typology of segmentation of employment is constructed that show, in addition to the specificities of each country, the similarities in the structuring of the labour market.
\end{abstract}

Keywords Labour market segmentation $\cdot$ Structural heterogeneity $\cdot$ Social inequalities $\cdot$ Segmentation typology $\cdot$ Europe $\cdot$ Latin America

\footnotetext{
P. López-Roldán $(\varangle)$

Centro de Estudios Sociológicos sobre la Vida Cotidiana y el Trabajo - Instituto de Estudios del Trabajo, Universidad Autónoma de Barcelona, Barcelona, Spain

e-mail: Pedro.Lopez.Roldan@uab.es

R. Semenza

Dipartimento di Scienze Sociali e Politiche, Università degli Studi di Milano, Milano, Italy e-mail: renata.semenza@unimi.it
}

\author{
A. Salvia \\ Observatorio de la Deuda Social Argentina, Universidad Católica Argentina, \\ Buenos Aires, Argentina \\ e-mail: agustin_salvia@uca.edu.ar
}




\subsection{Introduction}

The general purpose of this chapter is to perform a comparative analysis of the labour markets in Europe and Latin America, focusing on the cases of Spain and Argentina, in order to develop a model for analysis from the perspective of labour market segmentation and thereby explain the processes of social inequality in terms of employment. The proposal is to do so by applying a single method of analysis to ensure coherent comparison of the structures of the inequalities in both labour markets, on the understanding that the two cases involve different institutional contexts and levels of economic development.

There are two objectives. The first is to conduct a comparative descriptive analysis of the main characteristics of labour markets in European (Spain, Italy, France, Great Britain and Finland) and Latin American (Argentina, Chile, Brazil, Mexico and Uruguay) INCASI member countries in the context of a selection of 60 countries from both territories. Using a series of indicators on the functions and structures of the labour markets in these countries, the main patterns that differentiate each of them are identified. This information presents the situation regarding labour in each country, revealing the common specificities and characteristics, and leading to the construction of a typology of models for the general structure of labour markets.

The second and principal objective is to propose a model for comparative analysis of labour inequality processes from the theoretical perspective of labour market segmentation and structural heterogeneity. After explaining the conceptual foundations of the analysis model, the following initial general hypothesis is formulated: European and Latin American countries, with clearly differentiated characteristics both in terms of economic structure and level of development, and with specific institutional frameworks and socio-historical processes, present similar dynamics in terms of structure of the capitalist labour market on the basis of a classification of labour segments of similar characteristics that structurally differentiates between a primary and secondary segment. To investigate this hypothesis, we shall focus the study on two chosen project countries: Spain and Argentina, which were both late to develop capitalism, although in clearly different socio-historical and institutional contexts. Using equivalent databases on the workforces in each country and standardising the information for comparative analysis, we produce a typology of labour segmentation in each country that presents the similarities in their labour market structures and their expression in terms of labour and social inequality. Hence our thesis is that there are common patterns of labour segmentation that are explained by the confluence of supply and demand factors in each country, albeit operated from particular institutional and developmental contexts and dynamics for which reason we require specific explanatory factors of these general shared mechanisms.

One of the classic concerns of sociology has been to identify the sources of social inequality. In contrast to the expectations of social theory (Parsons 1951), according to which modernisation has led to convergence and a reduction in disparities in income, consumption and lifestyles, inequalities have increased in global and 
technological societies. Under the pressure of economic-organisational, politicalinstitutional and social changes (Crouch 2014), labour markets are part of the scenario of globalisation and the development of digital technologies, whose combination is leading to a new international division of labour. The expansion of the tertiary sector and the decline of traditional institutions that oversee collective industrial relations are leading to an increase in non-standard labour conditions and new kinds of professionals in emerging economic sectors (Semenza and Pichault 2019), associated to platform capitalism, the sharing economy and the gig economy. A broader socio-economic debate has developed regarding the inequality generated by the processes of categorising and hierarchizing the workforce, which assign workers to positions inside, outside or in between company boundaries (Granovetter and Tilly 1988). In short, we can speak of a new scenario that involves the combination of four general questions.

The first and most important refers to globalisation and the Global Value Chain (GVC) (Gereffi et al. 2005), in production, in the fragmentation of production processes and, therefore, in the growth of a huge freedom of use by firms of the labour factor. Companies can work with very different labour systems and use them selectively, and decide how to move production and what to move, without the slightest possibility of impact on the part of the unions. In the presence of a new type of internet-based company and of outsourcing that produces a chain of contracts and subcontracts, labour conditions within a company are extremely guided by relations with other national, multinational and foreign companies. Labour markets are influenced by the transnational migration of workers, which affects employment and wage levels.

The second is the question of technology, which has a decisive influence on the kinds of work and the organisation of labour and refers to the impact of digital technologies on productivity, subjectivity and quality of labour. Many labour activities and jobs are expected to disappear in the coming years (Frey and Osborne 2017; Arntz et al. 2016). Unions continue to control and defend a labour structure that is becoming obsolete, and have yet to enter the circuits of digital technologies.

The theory of a capitalist 'networked society' (Castells 2000) focuses on the spread of digital social networks across national borders and into almost all of society's subsystems. The global information economy is based on the extraordinary power of information and communication technologies to coordinate markets and a large number of social functions. Conflicts, inequalities and social exclusion are increasingly arising from the effects of network structures.

The third general question is job instability, which has spread to all sectors of activity, and even professional and managerial positions are being hit (Kalleberg 2009; Standing 2011). Since the 1990s, socio-economic debate has viewed a flexible labour market to be the organisational solution to enable companies to adapt more easily to market fluctuations, increasing their performance through a reduction in surplus labour. The different forms of instability have increased in all developed economies, as an unavoidable aspect of the new forms of business organisation that are typical of so-called slim, post-industrial capitalism. However, the different 
sectors of the labour market have not all participated in these changes to the same extent.

A fourth question concerns the processes of structural exclusion of the workforce that, as a result of unequal and heterogeneous capitalist development across regions, sectors and occupational profiles, are happening in both advanced and underdeveloped societies, leading to an aggregate demand for formal employment that is unable to fully absorb all of the available labour supply. This has meant that the worldwide reduction in unemployment has not been accompanied by improvements in the quality of work (ILO 2019). So there is still a worrying issue of labour poverty, poor quality employment and persistent inequalities in the labour market. This process tends to be worse both in central and medium-developed countries as a result of technological changes and productive reconversion processes, the crisis of traditional forms of employment in local economies, the emergence of new businesses and illegal forms of unstable work, the renewed pressure generated by forced migration on an international level, the divergences in demographic transitions in terms of social inequality, and many other factors. Among the issues to highlight is the on-going divide between women and men in employment. These trends seem to have taken a new direction in the current context of globalisation, and national social security systems are unable to meet the welfare requirements arising from this situation, which is expressed by such persistent phenomena as forced inactivity, chronic unemployment and the many forms of poverty and marginalisation of labour.

In these main contexts of change, inequality is not always expressed the same way, because it involves different dimensions and may change over time. By focusing on an analysis of the way the labour market operates, we will particularly be putting ourselves in a paradigmatic position from which to observe social inequalities as an interplay of processes and dynamics from unequal positions of origin that are then reproduced, and others that are generated in this area, but also without denying the existence of the phenomena of upward occupational mobility.

Various theoretical perspectives deal with the representation of inequalities in modern society. From this perspective, we observe a shift from a concept based on 'inequality of conditions', which refers to the unequal distribution of income, wealth and material goods, to the idea of 'inequality of opportunities', which refers to the unequal distribution of life opportunities. In consequence, a representation of inequality involves discerning which groups or individuals are victims, in accordance with a model of social justice based more on equal opportunities (as a starting point) than on achieving equal conditions (as an arrival point). In contrast to the model that had characterised the phase of Fordist capitalism and its class structure, the new model supposes that individuals have the same opportunities to achieve certain social conditions (for example, through education), no matter how unequal they are (Dubet 2010). This is a means to legitimise the 'correct inequalities' derived from individual responsibilities, in a manner consistent with what Beck and BeckGernsheim (2001) called the 'individualisation' of modern societies, to show how institutions and social organisation reclassify the processes of exclusion and discrimination as a result of individual career paths and choices. Since the 1980s, both social theories and public discourse have gradually shifted from the structural 
sources of inequalities, where the state and institutions play a key role in increasing or reducing socioeconomic disparities, to the inequality that arises out of individual responsibilities and is attributed to personal characteristics.

A second observable aspect is that the attention given to inequalities is focused more today on 'income inequalities' within developed western economies than on 'social inequalities'. As Ramos Pinto (2016) pointed out, we are witnessing the predominance of the 'income inequality' approach, as represented so well by Piketty's (2013) worthy demonstration of how the concentration of personal wealth has grown since 1980. It is somewhat narrow-minded to only view personal attributes as responsible for income mobility. From the point of view of social scientists, and from sociology in particular, the hegemony of economic methods, the reconstruction of patterns of income distribution and language, have limited a potentially broader understanding of inequalities. ${ }^{1}$

The availability of international data series means it is possible to measure inequalities between countries. In Europe, we observe a dual effect of inequality. Although the process of European economic integration led to a reduction in inequalities between nations up to 2008 , that convergence was partially interrupted by the effects of the economic and financial crisis and austerity policies. These have produced, as is well known, different consequences for the standard of living among Europeans, with an increase in poverty especially in the countries of southern Europe, compared to the Scandinavian countries and continental Europe. Therefore, there is significant inequality within the European Union on a territorial level.

However, together with this geographical divide, a second dimension of inequality is observed, based on the image of social differentiation in the European population, which is common and transversal to all national contexts. The socio-demographic characteristics that differentiate people (young or old, male or female, migrant or native, high or low level of education and skills) largely determine their life, career and income prospects.

The thesis of the 'dualization of inequality' (Heidenreich 2016), which refers in particular to the current situation in the European labour market, particularly highlights this dual level of geographical inequality and social stratification. While the inequalities between developed and emerging/developing economies have been reduced, internal social differentiation within countries and between regions, firms, sectors of activity, and even more between social groups and worker categories, is increasing, especially when considering the broader coordination and fragmentation of labour conditions and contracts. The inequalities related to belonging to one social group as opposed to another are clearly observable. Generational inequality

\footnotetext{
${ }^{1}$ Tony Atkinson, who made an extraordinary contribution to the measurement of inequality and poverty, viewed income inequality from an unconventional perspective, namely the loss of social welfare associated to an unequal distribution of income. In other words, he considered the analysis of inequality as a basis for policies and suggested a series of concrete measures to reduce it. Atkinson's (2015) ultimate goal was to transform economic analysis into political action, and hence he recommended new and ambitious policies in five areas: technology, employment, social security, capital distribution and taxes.
} 
in career paths (effects of age-based discrimination), inequality in terms of income production and inequality in access to social protection are paradigmatic.

The main drivers of change (globalisation, technological progress and instability) cannot be separated from specific national factors, such as the choices made by governments regarding taxes and social protection. In fact, in all nations we can observe a variety of different ways to organise society and distribute income and opportunities, and which vary substantially in terms of the scope and efficiency to reduce inequality. For example, in such an emblematically egalitarian society as Sweden, a new tax policy and certain reforms of the welfare state are changing the distribution of income, benefitting the wealthier classes ahead of the rest of the population. In other words, "it costs less to be rich" (Pelling 2019).

The intensification of economic and social inequalities within labour markets, whose homogeneity was a prerogative of the Fordist system, implies the need to rethink the fundamental link between economic efficiency and social justice, which has been so crucial for European democracies that have widely reduced investments in welfare policies, diminishing the role of the state in mitigating risks.

The analysis of these issues from the perspective of labour market segmentation offers a paradigmatic vantage point from which to observe social inequalities, and led us to propose a methodological strategy for comparative analysis between countries that is open to the possibility of producing theoretical formulations that cross a society's boundaries (Holt and Turner 1970). This comparative methodology is designed from the recognition of the existing duality, in macro-social units, between similar systems and different systems (Caïs 1997) with the aim to explain convergences and divergences of social processes in time and space. We do this in the text by first comparing, for contextual reasons, the position of a wide selection of European and Latin American countries in terms of a selection of labour market indicators, and, second, by examining the particular cases of Spain and Argentina through the formulation of an analysis method that is theoretically grounded on the perspective of segmentation and structural heterogeneity. From these analyses, we shall draw relevant conclusions to advance in this line of comparative international research.

\subsection{Characterisation of European and Latin American Labour Markets}

The defining features of the labour markets in both continents clearly reveal major differences in relation to certain structural aspects that have arisen out of contrasting levels of development, dynamics and particular economic-productive structures, as well as specific historical processes and institutionalisations of labour relations. We shall first present this contrast in the form of the existing socioeconomic distances between these countries, while also revealing the profiles that seem to form groups, thereby configuring a general descriptive typology. 
We will consider, on the one hand, a selection of Latin American and European countries for which we have a set of comparable indicators based on the proposal produced by the International Labour Office and contained in the 17 Key Indicators of the Labour Market -KLIM- (ILO 2016). Specifically, the variables highlighted in Table 3.1 have been considered for an initial selection of 60 European and Latin American countries for which we have sufficient data.

To synthesise and structure all of the information on these 13 indicators for the 60 selected countries, a principal component analysis is applied in order to obtain the most important patterns that differentiate between countries, together with a cluster analysis to group the countries that most resemble each other in a general classification of labour markets.

Figure 3.1 shows the results obtained from the two main factorial axes that accumulate $68 \%$ of the variance explained. Factor 1 accumulates most of the variance, $51 \%$, and reveals a latent dimension associated with a greater or lesser level of development. In this dimension, the negative polarity includes long hours of work, high levels of employment in the agricultural sector and a high proportion of young people who do not work or study, as well as low levels for the variables that define the other polarity of that main dimension, the positive one, namely high productivity, the importance of the service sector, high occupational status and educational levels, high salaries, high income and a framework of labour relations with a considerable presence of unions and coverage of bargaining. As shown in the graph, most of the most developed European countries are located towards the extreme of

Table 3.1 Selected key indicators of the labour market

\begin{tabular}{l|l|l}
\hline $\begin{array}{l}\text { No. of } \\
\text { variable }\end{array}$ & $\begin{array}{l}\text { KLIM } \\
\text { number }\end{array}$ & KLIM Indicator \\
\hline 1 & 1 & Employment-to-population ratio \\
\hline 2 & 2 & Status in employment: employees \\
\hline 3 & 3 & Employment by sector: agriculture and services \\
\hline 4 & 4 & $\begin{array}{l}\text { Employment by occupation: Managers, professionals and } \\
\text { technics }\end{array}$ \\
\hline 5 & 5 & Employment by education: advanced level \\
\hline 6 & 6 & Hours of work \\
\hline 7 & 8 & Unemployment rate \\
\hline 9 & 9 & Labour underutilization \\
\hline 10 & 10 & Youth not in employment, education or training (NEET rate). \\
\hline 11 & 12 & Monthly earnings \\
\hline 12 & 14 & Labour productivity \\
\hline 13 & 16 & Labour dependency ratio \\
\hline
\end{tabular}

Source: International Labour Office, 2016

KLIM variables: 7. Informal employment, 11. Time-related underemployment, 13. Labour costs and 15. Employment by economic class, are not considered in the absence of data for many countries 


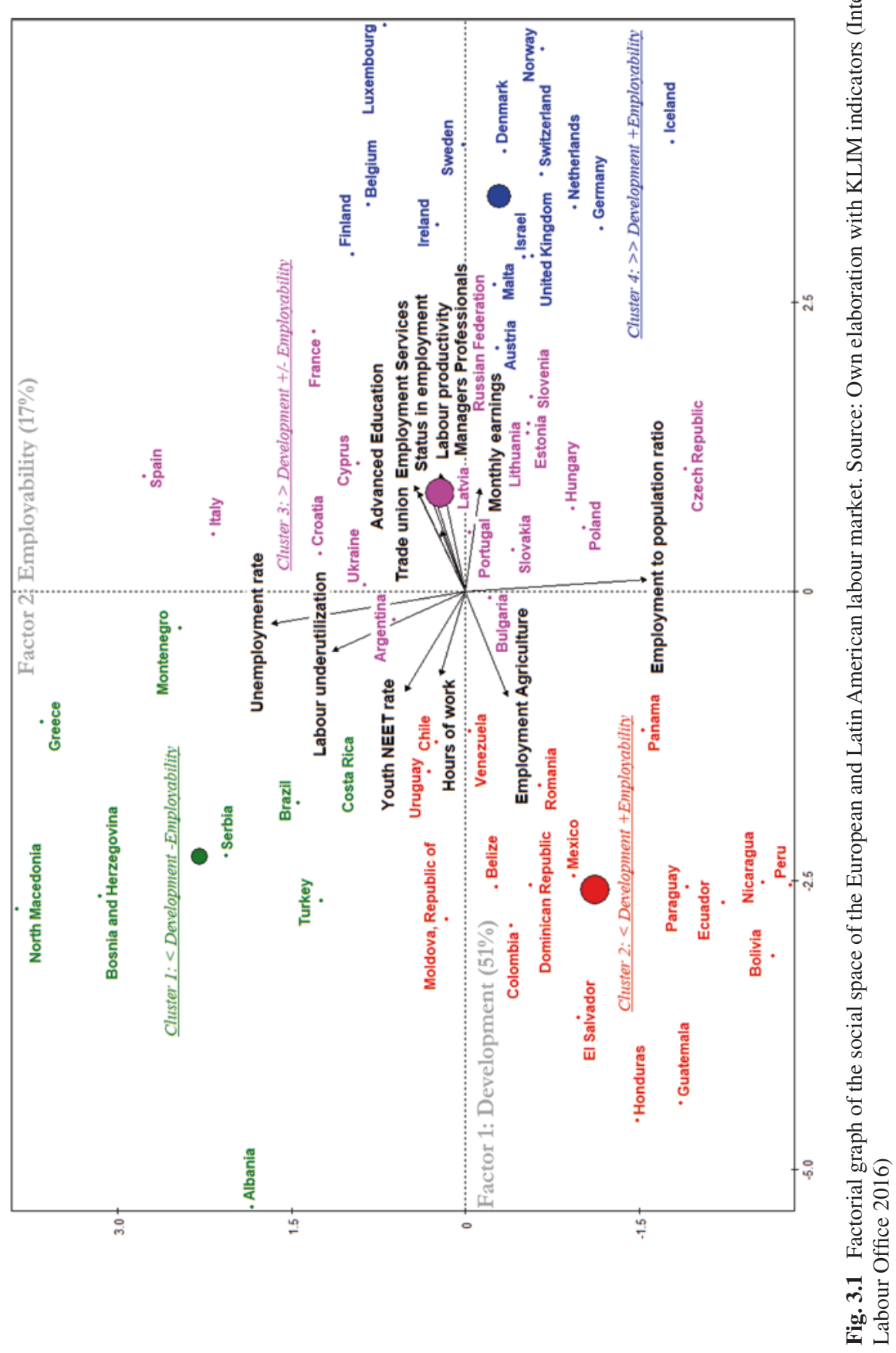


this latter polarity, while most but not all Latin American countries are located in the former.

Factor 2, with less important $17 \%$ of the variance explained, expresses a dimension associated with employability. It contrasts, on the one hand, high levels of activity or employment against high levels of unemployment and underutilisation of the workforce, on the other. This factor contributes to an internal differentiation of the features mentioned with regard to the first dimension, whereby most of the Latin American countries, which have higher levels of employability, are separated from the less developed European countries with low employability. Meanwhile, the most developed European countries, despite not differing so much in terms of this aspect of employability, do present certain differences between the more Mediterranean countries with lower employability levels and the Eastern countries with higher levels.

So, depending on these two factors, four types of countries are configured as shown by the colours in Fig. 3.1. Groups 1 and 2 share the features of less development and differ in terms of employability. Group 2 includes most Latin American countries, along with Romania, while Group 1 includes the least developed European countries with the lowest employability, along with Costa Rica and Brazil. Groups 3 and 4 are those with the highest levels of development, differing along a scale between those of the highest level in Group 4, essentially the countries of central and northern Europe, and the countries in Group 3, which are mostly from the south and east. In the latter case, in addition to the internal differences as mentioned in terms of employability, Argentina is also included on the outer limit of the group.

Spain and Argentina are the two countries that we have chosen for the comparison that we shall be examining in greater depth later on. These two countries are in an intermediate position in the development dimension, Spain being more highly placed, and with differences in the level of employability, which is higher in Argentina, due to the significant unemployment rates in the Mediterranean country and the relevance of the informal sector in the latter's economy, which benefits, albeit in instable conditions, the employability of the population. Meanwhile, both countries have different social models, as explained in the previous chapter. Spain is characterised by a mixed or semi-coordinated economy, while Argentina identifies with an informal uncoordinated economic system.

\subsection{Inequality in the Labour Market from the Perspective of Segmentation}

Our perspective in this chapter deals with the characteristics and conditions under which segmented labour markets operate in Europe and Latin America, in other words their effects in terms of flexibility and instability, i.e. job quality. Labour and employment segments are also viewed as the expression of the structure of social inequalities in the productive labour market, and the crystallisation of the social 
logic that coordinates the time and work of the production and reproduction of life in a social and institutional context that models them. To present the social processes underlying the social inequalities that are generated in the labour market, our perspective combines two main theoretical approaches: the perspective of labour market segmentation and the perspective of structural heterogeneity.

First, to explain how the labour market works and the persistent labour inequalities that arise from it, we take the theoretical perspective of segmentation, whereby it is argued that the adjustment between supply and demand as a result of competitive allocation based on wage productivity, technological changes and trends in economic growth, is an insufficient explanatory mechanism to account for differences in wages and career paths, and the unequal positions that are generated in terms of labour conditions and job quality.

From this perspective, we stress the need to consider the institutional aspects that affect the labour market, the strategies of the parties involved taking into account the system of labour relations, with its regulatory framework and collective bargaining, different social and welfare policies, the social characteristics of the workforce, the sexual division of labour, as well as contextual elements of national production structures, of the global economy and of economic cycles, in a capitalist system dominated by neoliberal policies.

These different elements affect the configuration of common general dynamics regarding the division of labour and employment in terms of segmentation, beyond specific local or national configurations. Following Grimshaw et al. (2017) we propose the adoption of a multidimensional perspective involving factors that explain how the labour market works and how labour inequalities are generated. The revised proposal by Grimshaw et al. (2017), inspired by the intellectual contributions by Jill Rubery and the Cambridge school, as well as the International Working Party on Labour Market Segmentation, proposes a combination of three theoretical traditions to account for inequalities in work and employment: labour market segmentation, comparative institutionalism and the feminist socioeconomic approach. We now briefly account for each of these three aspects, in relation to which then we produce

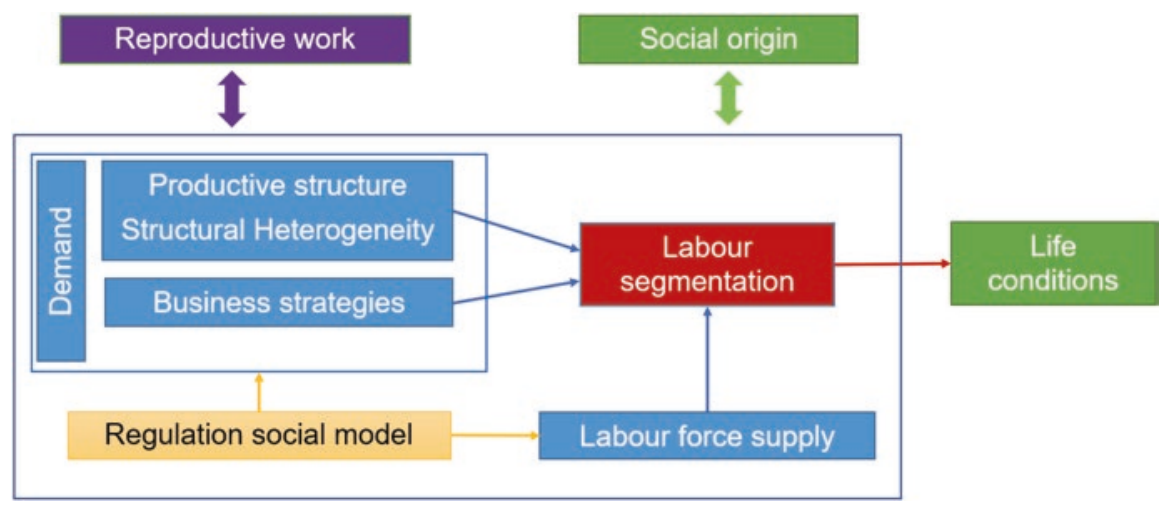

Fig. 3.2 Labour market segmentation. Analysis model 
a specific model of analysis adapted to the study of employment as illustrated schematically in Fig. 3.2.

First, from the perspective of segmentation, and in contrast to the traditional postulates of neoclassical economics, the demand side must be viewed as fundamental. At the centre of the analysis are found the business strategies for the organisation of production and labour (especially flexibilisation, outsourcing and subcontracting) that, seeking to maximise profits by minimising costs and controlling the workforce, generate unequal labour conditions and opportunities for the salaried working population, and consequently for their career paths. However, inequalities are also reproduced and arise in interaction with the supply side. Certain social characteristics of workers hired both formally and informally, such as class, gender, age, immigrant origin or race, are unevenly distributed and overlapped according to the configuration of segmented jobs, thus favouring the ultimate goals of employers. Inequalities are thus constructed, creating hierarchical employment segments and career paths, of greater or lesser quality, filled by people from different social profiles, which the segmentationist literature has identified in terms of the duality of the labour market, differentiating between a primary and a secondary segment. This idea has been raised, in general terms, in numerous contributions since the 1970s, including among many others Doeringer and Piore (1971), Rubery (1978, 2005, 2007), Gordon et al. (1982), Wilkinson (1981), Craig et al. (1982), Recio (1991), Grimshaw and Rubery (2005), Gibert (2011) and López-Roldán and Fachelli (2019).

Secondly, from comparative institutionalist theory, the societal effect derived from the role of institutions and the power relations between stakeholders is considered a fundamental issue for explaining the configuration and workings of the labour market. From this perspective, aside from the logic of conflict between capital and labour, we also need to consider the rules and standards that sustain education and vocational training systems, the welfare state and social protection systems, gender relations, organisation of families and homes, labour relations, behaviour in the workplace and business cultures, corporate governance and innovation systems. The interaction between these elements structures the observable inequalities in labour and employment. In this regard, we may speak of varieties of capitalism. In particular, the regulatory regime of each nation state establishes a specific framework for modulating the labour market and its effects in terms of labour inequalities, whereby it accompanies and reinforces, with greater or lesser emphasis depending on the employment model and the policies applied, inequalities and the segmentation of the labour market, heightening the risk of exclusion of some of the weakest workers, generating far from decent job conditions and even threatening the quality of jobs for the highest ranked groups. Hence, the contextual institutional elements offer specific explanations for the phenomenon of segmentation, avoiding overly simplistic universal theorisations of a phenomenon that can nevertheless be considered widespread across capitalist economies. Studies along such lines include those by Esping-Andersen (2000), Hall and Soskice (2001), Menz (2008), VaughanWhitehead (2015), Burroni (2016), Del Pino and Rubio (2016) and Doellgast et al. (2018). Meanwhile, segmentation is dynamically expressed in terms of mobility 
processes and career paths that also express processes of labour inequality (Miguélez and López-Roldán 2014; Verd and López-Andreu 2016; Martín Artiles et al. 2018).

Thirdly, the tradition of feminist socioeconomics has focused the study of segmentation processes in terms of gender inequality, broadening the perspective and breaking away from androcentric views focused on the productive sphere. From a broad vision of the concept of work, taking into account the interaction between the productive and reproductive spheres, and revealing the segregation and discrimination of women in terms of labour (Humphries and Rubery 1984, Bettio and Verashchagina 2009), the segmentation model has a strong capacity for explaining the mechanisms that underlie the generation of labour and social inequalities. The inequalities observed in work and employment between men and women are explained by the confluence of different elements: the sexual division of labour, the persistence of a social and cultural context of patriarchal dominance, the reproduction of the tendency among employers to devalue and segregate female labour, or the interconnections between the welfare and care systems, the regulation of labour and the way the labour market functions (Bettio and Plantenga 2004; Simonazzi 2009), as has been made apparent for Spain (Carrasquer et al. 2015). These developments serve to explain the different career paths of men and women (Borrás et al. 2012; Torns et al. 2013; Carrasquer and Amaral 2019), as well as the different gender impacts of the 'Great Recession' (Rubery 2014; González Gago and Segales Kirzner 2014; Kushi and McManus 2018; Sánchez-Mira and O’Reilly 2018).

These three core areas of segmentalist theory can also be framed in an analysis of the patterns and trends in changes in the global economy, as well as in the specific context of a territory's productive structure and level of economic development.

It is particularly in this regard that we contemplate the perspective of structural heterogeneity. This approach was introduced by Prebisch (1949) and formalised in the 1970s by Pinto (1970) and later PREALC (1978), and is still in force today in the conceptual framework of CEPAL (2012). This approach takes the perspective of historical structuralism to understand the economic and social workings of Latin American countries. According to this theory, in capitalist economies subject to an unequal, combined and dependent development model (the dominant one in Latin America), modern, high productivity production sectors, integrated into world markets, with similar labour organisations and relations to those of the most developed countries coexist alongside very low productivity production sectors that are mainly focused on the domestic market, linked to social subsistence needs and involving informal economic units or activities. The existence of an absolute surplus of labour and labour segmentation would be a consequence of these productive constraints whose corollary would be the segmentation of jobs in the labour market into subsistence activities typical of the secondary segment and formal jobs in the formal private and public sectors typical of the primary segment, and hence inequalities in living conditions that are persistent over time (Salvia 2012).

This social dynamic is expressed in the mechanisms for the selection, opening or closing of opportunities through economic agents and regulatory institutions at the level of each market. Labour inequality is structured around certain groups (young people, women, migrants, unskilled, etc.), as well as economic-occupational sectors 
and segments that are affected by conditions of structural heterogeneity: nonprofessional self-employed workers, informal micro-units, social cooperatives, destitute jobs, etc. So, one of the sources of the inequalities that arise in the labour market is the incidence of a production structure that segments positions and, in turn, is the cause of its structural effects on different processes and dimensions that shape unequal living conditions.

Given certain initial conditions for social inequality and reproduction, particularly in the sexual division of productive and reproductive labour, the dynamics of the labour market's interaction with these initial conditions are expressed in its segmentation as a result of the interaction of four central elements: the socio-economic productive structure, business strategies for production and organisation of labour, the institutional structure that regulates social relations in terms of labour that shape a certain social model of employment and the social characteristics of the workforce.

We understand that to account for inequalities in the labour market, it is essential to verify the existence of a production structure that determines the characteristics of employment and the structure of the labour market. This socio-historically rooted factor is associated to productive forces and regulatory institutions, but implies accounting for a mechanism via which the segmentation of the labour market is configured, and which both structural heterogeneity theory in Latin America and non-orthodox theories on labour market segmentation have expressed. From this theoretical perspective, our general hypothesis, which we shall shortly be analysing for the comparative cases of Spain and Argentina, will establish, on the one hand, that there is no single market that adjusts supply and demand but that different hierarchical segments are configured depending on job quality and, on the other, in terms of employment, that we expect to find a similar general structure of the labour markets in Spain and Argentina.

\subsection{Comparative Analysis of Labour Market Segmentation in Spain and Argentina}

If we analyse both countries in terms of the social model developed in Chap. 2, where the labour relations model and the welfare model were interrelated as regulatory institutions to correct social inequalities from the pre-distributive or postdistributive point of view, we find that Spain and Argentina have two different models. Spain's is that of a mixed or semi-coordinated economy, characteristic of Mediterranean countries, while Argentina's is typical of Latin America, namely an informal uncoordinated economy. We now describe some of these specific features of the context of each country. 


\subsubsection{The Context of the Spanish Labour Market}

The Spanish labour market has historically been characterised by large fluctuations in the volume of employment (Banyuls and Recio 2017), plus high levels of unemployment and temporary employment and hence labour segmentation, generating the social phenomenon of flexible employment (Prieto 2002; Miguélez 2004). Public employment policies have been implemented in a context of debate over the supposed rigidity of the labour market in terms of recruitment and the negotiation of wages. However, statistics show that it is actually a country that has maintained Europe's highest levels of atypical employment over time, due to the specificity of its employment model (Bosch et al. 2009). There is no ignoring the persistence of a production structure and certain business strategies that have generated a labour market with high rates of temporary work and unemployment (Fina and Toharia 1987; Banyuls and Recio 2017).

The Spanish employment model is identified as Mediterranean neoliberal (Banyuls et al. 2009) where different characteristics are combined within a socioeconomic model resulting from rapid and profound changes in which structures and dynamics inherited from the dictatorship converge with major transformations that have been implanted in times of democracy. This model is the result of the convergence of various defining characteristics: a service productive structure with a predominance of small and medium enterprises, with particularly intensive use of labour, low qualifications and relatively low productivity; a production system that is isolated from the education system; Taylorist business practices, with cost-cutting strategies and external flexibilisation of labour management with scant interest in training; an economy that includes a relatively large amount of undeclared labour; a low number of large high technology companies; and union action mainly being limited to large companies and unable to operate in the broad network of small companies, even though the unions are well recognised and institutionally legitimated. All of this has led to and maintained high segmentation of the labour market and high levels of unemployment.

To this is added a weak welfare system, where, although we should also recognise that the state has improved its services and benefits since the establishment of democracy, the fiscal system and policies that restrict the public sector have yet to fully resolve, in comparison to the rest of Europe, the inequalities that this employment model generates and which has to be compensated by generous family support, with the effects that this entails when it comes to ending gender inequalities if a fair social model is to be defended in terms of the distribution of everyday time and activities.

In this power struggle, we should first note that Spain's production structure has always been characterised by the importance of labour-intensive low productivity activities. During modernisation, a cumulative process has occurred whereby the service sector has expanded at the expense of agriculture and industry on the basis of business policies promoting low-cost labour, flexible labour management and control of the workforce. Hence the growth in productivity has generally been very 
moderate. The predominance of a broad network of small and medium enterprises has reinforced this strategy and largely explains the weak competitive position of many activities with little added value. Large companies, meanwhile, are concentrated in sectors such as banking, construction, tourism and public services, generating limited surpluses, little technological innovation and a weak position in the international economy.

Second, in times of democracy, labour relations have involved the major institutionalisation of trade unions and business organisations. This can be identified with a model that Hall and Soskice (2001), when discussing varieties of capitalism, call coordinated economies, where neo-corporatist structures to institutionalise social consensus exist alongside collective bargaining. In Spain, this neo-corporatism would be of a medium or mixed level, where tripartite social dialogue has typically been produced via external institutional mechanisms, focused on issues related to the labour market and social policy, adopting a strong distributive nature and having little impact on the formulation of general economic policies, and acting in an intermittent manner depending on the economic cycle and the policies of the party in power (Molina and Miguélez 2016). In the particular case of trade unions, general bargaining is legitimised, and unions have participated in different tripartite agreements throughout democracy, but they are too weak to guarantee compliance with these agreements, since their presence in small and medium enterprises is so limited. This situation dualises trade union action and reinforces the segmentation process, since the unions are strong in large companies, where jobs are predominantly of good quality, and weak in small companies, which are the ones that experience the effects of the different policies that are leading to segmentation (AlósMoner 2008).

Thirdly, we note that since the transition to democracy numerous labour reforms have sought to regulate the Spanish labour market. There was a major turning point in 1984 with the act that abolished the 'causality principle' that was typically included in temporary contracts. Since then, successive reforms have introduced measures to deregulate and flexibilise contracts and these have helped to bring the costs of temporary and indefinite contracts more in line, while also maintaining a high proportion of poor quality work without changing the preference among employers for temporary contracts (Toharia 2011). The general aim of the process has been to reduce labour costs, and this has discouraged innovation and qualified jobs, leading to stronger labour market segmentation. In addition to these partial reforms, there have also been marginal attempts to weaken the capacity for collective bargaining or limit unemployment benefits. This has especially been the case since the 2012 reform that decentralised and prioritised bargaining at the company level, giving employers a greater margin for discretion when differentiating labour conditions and inequalities (Cebrián et al. 2013; Martín Artiles et al. 2017; AlòsMoner et al. 2017). The tension between the implementation of more liberal policies and resistance to the same has tipped the scales more towards neoliberal capitalism in line with international trends.

This tension has also been expressed in the construction of a welfare state that is limited by neoliberal policies aimed at reducing the role of the state in the economy 
and society. However, the Spanish Mediterranean regime, rooted in its cultural patterns, with the indispensable provider role of families and ever-persistent gender divisions, has expanded considerably, although its social protection function has suffered the contradictions of that tension with cuts in public spending, a good part of which is concentrated on unemployment benefits and subsidies, with little investment in active employment and training policies, which are below the European average. Early school dropout, the limited weight of vocational training and high levels of underemployment of young people with a high level of education continue to be the touchstones of Spanish society. Meanwhile, attempts to reduce gender inequalities by balancing domestic and care work with paid work have been a slow process, especially in the private sector, although the highly widespread incorporation of women into the labour market means that the country is irreversibly headed towards increasing reduction of the gender divide. The effects that this situation will have on the future of the pension system, given the decrease in contributions and demographic trends, are another matter entirely.

In summary, we could speak of diverse and contradictory dynamics in a universal welfare system that is characterised, in relation to European levels, as being of low quality and low cost (Martín-Artiles 2008; Banyuls et al. 2009). The last 40 years have produced profound and rapid changes that have led to the modernisation of the country, but it is one where the structural dynamics and problems that reproduce social inequalities persist. It is a system whose weaknesses re-emerge and worsen in crisis situations such as the Great Recession of 2008, and the current phase of slow recovery has failed to get the country back to its pre-crisis levels.

\subsubsection{The Context of the Argentinian Labour Market}

In the last five decades, Argentinian society has experienced major on-going economic-financial instabilities, which have had regressive effects on the labour market, both in terms of job creation and the evolution of real wages and the amount of informal labour, among other aspects (Salvia et al. 2018). This labour market behaviour was not unrelated to the performance of the production structure, the macro-economy and labour institutions. The latter, in turn, has proven to be highly endogenous to changes in macroeconomic models and political-economic cycles and conjunctures (Bertranou and Casanova 2015).

It is in this context that we should understand the particular increase in poverty and social inequality in recent decades in a country that has a high potential for production and major competitive advantages for the production of primary goods on an international level. The structural heterogeneity of the labour market, its increasing segmentation and the formation of a large sector of surplus population taking refuge in informal activities (Bertranou et al. 2013), are persistent underlying factors of the regime of accumulation in Argentina. These are still distinctive aspects of the way the labour market works in the country, even despite the recovery and 
formalisation of employment in each cycle of expansion (Salvia 2014; Salvia and Rubio 2019; Poy 2017).

In the last 30 years of Argentinian history, the labour market has acted in different and contrasting ways. In the late 1990s, not only did unemployment rise, but job quality deteriorated too, as a result of the increase in informal labour and unstable employment in the formal segment. Following the socioeconomic crisis of the start of the century (2001-2002), labour market indicators improved, unemployment fell and there was an increase in formal paid employment. However, from 2009, in a context of greater economic volatility, these improvements tended to stagnate, or even drop off, particularly following the crises of 2014-2016-2018, and partially regressive reforms to labour policies from 2016 onwards.

In the 1990s, in a context of structural reforms and economic liberalisation across almost the entire region, the demand for employment in the Argentine labour market was extremely un-dynamic, with significant increases in the levels of unemployment and unstable work. In this context, major reforms were made to labour regulations under the premise that greater contractual flexibility would boost the demand for employment, reduce labour costs and make businesses more competitive (Heckman and Pagés 2005; Marshall 2004; Neffa 2008). In terms of the regulation of labour, together with the creation of a limited unemployment insurance, the new regulations introduced fixed-term contracts, brought down severance costs and made them more flexible, endorsed unpaid forms of labour, promoted the decentralisation of collective bargaining, and also brought about changes in the labour organisation of companies without union mediation, and even sought to reduce contributions by employers to social security in order to encourage more flexible jobs. At the same time, a series of social employment and occupational training programmes were instituted for the unemployed in high-risk situations, to a large extent to reduce the social conflict generated by the restructure, closure and/or privatisation of state-owned companies (Salvia 2012).

In the 2000s, this concept was abandoned following the political crisis of the macroeconomic model in force during the period of neoliberal reforms. In the wake of the 2001-2002 crisis, in a context of strong economic growth and rapid recovery of the demand for employment, economic and labour policies aimed at creating quality jobs were put back on the public policy agenda. In a relatively short time, many of the reforms aimed at flexibilization that had been introduced in the previous decade were reversed. For example, flexible contracts were repealed, institutions linked to the setting of wages were revitalised and active policies for the protection of formal jobs were promoted (MTEySS 2009). The latter included measures to make it easier for workers to formally register, the recovery of statemanaged labour inspections, heavier sanctions on companies that committed labour fraud, and special tax regulations to promote the registration of labour among small and medium enterprises, as well as the creation of special regimes for registering female workers in private homes and agricultural labourers (Tomada 2014; Panigo and Neffa 2009). As for wage policy, on the one hand, there was a revival of sectorlevel collective bargaining, which led to a general recovery of wage levels, together with a fairer wage structure (Palomino and Trajtemberg 2007; Lanari 2015), and on 
the other there was the introduction of the Salario Minimo, Vital y Móvil (Minimum, Vital and Mobile Salary-SMVM) as a central instrument of income policy, giving powers to a tripartite collective body (Panigo and Neffa 2009).

But following the exhaustion of the economic model by the end of its first decade, coupled with the international economic crisis of 2009, labour policies had to be reappraised, primarily to safeguard jobs against the risks of economic openness and its effects on the unemployment rate. In this new setting, among other measures, the government implemented mechanisms to avoid collective redundancies, and expanded direct subsidies to cover the wages of affected companies. It also reintroduced vocational programmes aimed at unemployed people in the most vulnerable social segments in order to provide them with a minimum income.

In general, post-structural reform policies had positive effects on the labour market and improved workers' living conditions. However, its scope was still limited to the formal productive sectors, which, despite the economic growth and measures to promote formally paid jobs, continued to represent only $50 \%$ of workers and less than $70 \%$ of salaried employees. For them, the regulatory framework limits unstable labour relations, provides full coverage in terms of social security, health and indirect wages, and guarantees collective bargaining of wages; i.e. the degree of labour protection received by these workers is relatively satisfactory. However, other workers in the Argentine labour market see none of these benefits. Whether they are employees of small businesses, freelancers or social cooperatives, workers in the informal sector get absolutely no labour protection or social security. The only help they get from the Argentine government comes via conditioned income programs, which complement the very low wages that they can earn in informal labour markets.

Undoubtedly, macroeconomic and sector-level policies are an important part in the process of creating and formalising jobs in the Argentine labour market. However, labour institutions and policies also play an important role in the performance of the labour market, although the former are still insufficient to achieve full productive employment for the existing supply of labour, while the latter operate efficiently, but only with regard to a partial and relatively privileged segment of the workforce. Therefore, informal labour is still the main problem in terms of job quality given the limited number of atypical forms of employment within the formal segment (Salvia 2012; Bertranou et al. 2013). Both economic growth and changes to the production structure are fundamental elements for fostering quality jobs in Argentina.

This coincides with a period in which, as a result of factors related to the economy or not, growth in levels of activity has decreased and become more volatile and heterogeneous between sectors. Likewise, despite some changes to the production structure, the sectors that are able to generate high quality jobs currently have very little dragging, while foreign restrictions (as at other moments of Argentine history) are a major limitation on the growth of sectors with the capacity to generate jobs in the domestic market (Coatz et al. 2015; De Miguel and Woyecheszen 2015). 


\subsubsection{Analysis Model and Methodology}

In the comparative analysis of Spain and Argentina, from perspective of labour market segmentation and structural heterogeneity theory, we establish the general hypothesis that, on the one hand, there is no single market that adjusts supply and demand, but that different and hierarchized segments are configured, which depending on job quality are placed in two main groups: the primary segment and the secondary segment, where people are positioned unequally according to job conditions and such social characteristics as gender, age, immigrant origin and educational, as a result of the interaction between factors of supply and demand and a regulatory social model. On the other hand, we expect to find a similar structuring of labour markets in Spain and Argentina in terms of employment, in crystallization of labour inequalities resulting from structural and institutional processes that act as specific mechanisms in each social model, but which lead to similar general results in terms of the structure of inequalities in the labour market.

To test our hypothesis, we designed an analysis with a quantitative methodology that we present below. First of all, it is a static comparative study of the two countries with data for the year 2016 for the entire wage-earning population (72\% of the employed population for Argentina and $84 \%$ for Spain). Labour survey data is used to examine the labour market from an employment perspective, i.e. contract conditions and the quality thereof, and we do not specifically capture the characteristics of labour from the demand side contextualised in an organisation of production and labour, with effective functions and qualifications that are observable in the microsocial realities of jobs. We thus obtain a macro-social snapshot of an aggregate structuring of the segmentation of employment. This is a measure of the phenomenon that is expressed in terms of the results or effects of segmentation processes. Other factors are involved, such as institutional aspects, sector patterns, the framework of labour relations, the link with the reproductive sphere and other mesosocial matters, as we explained in our theoretical perspective, but these are not explicitly measured here. Those elements of our model are captured partially or indirectly.

Our labour segmentation model and its operationalisation are conditioned by the information available in the sources and by the need for comparable data between the two countries. Following the proposal formulated in López-Roldán (1996a) and López-Roldán and Fachelli (2019) indicators are distinguished from the points of view of both demand and supply, with a set of 8 dimensions that give rise to a total of 13 variables (Table 3.2). The dimensions that define the demand side are: security, as a dimension of job stability and instability; qualification, which differentiates formal occupational levels or professional categories; ${ }^{2}$ the wage dimension, as an indicator of job quality; and, finally, various characteristics of companies that

\footnotetext{
${ }^{2}$ As an indicator of skills, we use the International Standard Classification of Occupations, which hierarchically measures similar characteristics of the tasks involved in jobs and the training (competences) required to perform them, together with the performance of supervisory functions.
} 
Table 3.2 Dimensions and indicators of the employment segmentation model

\begin{tabular}{|c|c|}
\hline Dimension & Indicators/variables \\
\hline \multicolumn{2}{|c|}{ Labour market demand } \\
\hline 1. Security & $\begin{array}{l}\text { Type of contract and duration: Open-ended, }>6 \text { months, }<6 \text { months, } \\
\text { informal Type of workday: full-time, part-time Seniority in the } \\
\text { company: aggregation in months-years }\end{array}$ \\
\hline 2. Qualification & $\begin{array}{l}\text { Occupation: Managers and professionals, technicians and } \\
\text { administrative staff, skilled workers, unskilled workers } \\
\text { Supervision: Management, middle management, person in charge, } \\
\text { employee }\end{array}$ \\
\hline 3. Salary & Salary deciles: Decile 1 to Decile 10 \\
\hline $\begin{array}{l}\text { 4. Characterization of } \\
\text { the company }\end{array}$ & $\begin{array}{l}\text { Sector: Primary, } 3 \text { industries, construction, retail, transportation- } \\
\text { communications, financial-professional, public administration, other } \\
\text { services } \\
\text { Ownership of the company: Public, private } \\
\text { Size: }<5,6-10,11-49,50-250,>250 \text { workers }\end{array}$ \\
\hline \multicolumn{2}{|l|}{ Labour market supply } \\
\hline 5. Gender & Sex: Male, Female \\
\hline 6. Age & $\begin{array}{l}\text { Age: } 16-24,25-29,30-34,35-39,40-44,45-49,50-54,55-59 \text {, } \\
>59 \text { years }\end{array}$ \\
\hline 7. Immigration & Nationality: National, Foreign \\
\hline 8. Education & Educational level: Primary, Secondary, University \\
\hline
\end{tabular}

For some variables, the categorization will differ slightly depending on the source of information in each country.

contextualise the framework of social and organisational relations in which jobs are offered: company size, sector and ownership. From the supply side, four dimensions of the workforce are considered: gender, age, immigration and education.

The data for Spain is taken from the Encuesta de Población Activa (Active Population Survey) published by the Instituto Nacional de Estadística (INE), which equates to the European Union's EU-LFS, considering a total de 30,037 wageearning workers. For Argentina we use the fourth quarter of the Encuesta Permanente de Hogares (Permanent Survey of Homes) published by the Instituto Nacional de Estadística y Censos (INDEC), with a sample of 17,798 members of the wageearning population.

From the methodological point of view we pursue a dual objective. On the one hand, we seek to compare the factors that structure inequalities in the labour markets of Spain and Argentina and to determine the degree of similarity or dissimilarity of labour segmentation between the two countries. On the other, we seek to obtain a variable for the segmentation of the labour market in each country and thus compare the degree of similarity or dissimilarity between the labour segments that emerge from the analysis. Formally, the idea is to obtain a typology of employment segments defined in the form of 13 original variables and 74 associated categories. To do this, we apply a typology-building methodology that we call structural and articulated (López-Roldán 1996b) which principally involves sequentially combining two multivariable analysis techniques: multiple correspondence factor analysis, 
to analyse the relationship between the variables and synthesise them in a reduced set of factors of differentiation that define the factors that structure the labour market, and classification analysis, to group individuals into a number of employment groups or segments, the most internally homogeneous and the most heterogeneous from each other. In this process, the main factors obtained, synthetic and measured on a quantitative scale, are then used as classification criteria in the cluster analysis where a mixed method has been applied that combines Ward's method of ascending hierarchical clustering with an optimisation of the initial classification applying the mobile centres method (Lebart et al. 1997; López-Roldán and Fachelli 2015).

\subsubsection{Results of Segmentation Analysis in Spain and Argentina}

Table 3.4 in the Appendix shows the frequencies of the variables used in the analysis. The first dimension, that of job security, first considers the type of contract and its duration, where it is revealed that Spain has 15 percentile points more wageearners with indefinite jobs than Argentina. This difference is explained, in particular, by distinguishing feature of the Argentine labour market, namely the existence of a large informal labour sector of as much as $24 \%$ of paid employment, hence a situation of generally unstable work and the absence of recognised rights. This lack of contracts together with $15 \%$ temporary jobs implies a higher level of contractual insecurity that this indicator reflects: $39 \%$ in contrast to the $24 \%$ for Spain.

In this first dimension we also consider seniority in the company, whereby being in the same job for between 0 and 1 year is similar (17\%) in both countries. Argentina generally has a shorter-serving workforce, which is partly a product of a demographic effect, as it has a younger population than that of Spain, where $48 \%$ of workers have been in the same job for 5 years. In Spain, the proportion of the working population that has been in the same job for 4 years amounts to $70 \%$. Thirdly, we considered a standard employment indicator, from the stability dimension, to be the type of working day differentiating between full and part time. In Spain, the percentage of full-time employment is somewhat higher, $83 \%$, while in Argentina it is $78 \%$.

As for the second qualification dimension, the data shows that the occupational pyramid is more biased towards the top in Spain and towards the bottom in Argentina, with greater polarisation in the case of Spain. Executives, specialists and administrators amount to $44 \%$ in Spain, while in Argentina the value is 26\%. Meanwhile, skilled workers (with operational qualifications) amount to almost 50\% in Argentina while the figure for Spain is $41 \%$, in contrast to the greater weight in Argentina of unqualified salaried work: $27 \%$ as opposed to $14 \%$ in Spain. These profiles are complemented by an additional indicator in the qualification dimension that considers responsibilities for supervising other people's work. Spain has a greater degree of supervision (15\%) than Argentina (5\%).

On the matter of income, we have the aggregate information in deciles for both countries. 
For the dimension that characterises the firms in which the labour relationships occur, we collect various variables that reflect the organisational and sector-level contexts of jobs. First, the distribution by activity sectors shows one of the most important differences between the two countries, which occurs in the dimension of employment by public administration. This is the largest employment subsector in both countries, but in Argentina it is almost 6 percentile points higher. On the contrary, the trade and financial-professional sectors are notably more important in Spain than in Argentina, being almost twice as big in the former. Industrial subsectors also bear greater weight in Spain, 16\% compared to 13\% in Argentina, as do other services. However, the construction sector is somewhat more important in the Latin American country. ${ }^{3}$ As a result of this sector-level distribution, the dimension of public ownership of companies is the same in both countries, grouping a quarter of employment. As for company size, according to the indicator of the number of workers, the distributions are fairly similar, with a greater weight of smaller companies with 5 workers or fewer, which concentrate almost $27 \%$ of the paid labour in Argentina and $18 \%$ in Spain. For the other percentages, there are no major differences between the two countries.

In relation to the variables that describe the offer of employment, there are several differences between the two countries. First, the gender variable in Spain is balanced between male and female wage-earners, close to $50 \%$ each, while in Argentina women represent $45 \%$ of the total salaried population.

The age distribution data reveals an Argentine labour market with a greater percentage in the youngest group compared to the late entry by Spaniards in the labour market. 13\% of the Argentine workforce is in the 16-24 year age group, as opposed to just 5\% in Spain. The case is the same in the two next highest age brackets, but from the age of 35 it is Spain that has the highest percentages, reflecting the greater ageing in its wage-earning population pyramid, although in the oldest age group the numbers level off or even revert slightly back the other way.

The nationality indicator reveals another feature of the labour supply, with a greater weight of foreign labour in Spain, 8\% versus just over 5\% in Argentina.

Finally, the information on levels of education shows the unequal distribution between both countries: a more expansive education system in Spain has led to a low percentage of the population only having a primary education levels and a higher percentage that reached the highest levels. Almost $31 \%$ of the wage-earning population has a university degree, while the value is just $14 \%$ in Argentina, with a notably high $33 \%$ of the working population only having a primary education.

It can thus be concluded that there are major differences between the Spanish and Argentinian wage-earning labour markets, with higher qualifications and more stable jobs in Spain than in Argentina. The question we now ask is how this set of indicators can be used to present factors of inequality in the labour market, and to

\footnotetext{
${ }^{3}$ Note that the Argentine EPH primarily collects information from the urban population and underestimates the weight of the primary sector, so its introduction causes the commented values to vary somewhat.
} 
show which employment segments they occur in and the extent to which the two countries are similar.

\subsubsection{Labour Segmentation Factors}

In a first analysis we look to obtain the main factors of differentiation of the salaried workforce based on the interaction between the set of 13 chosen variables to express the dynamics of labour segmentation. These synthetic factors are obtained by combining the original categorical variables through application of a multiple correspondence factor analysis, with which we can parsimoniously reduce the data gathered by the initial multidimensional information on the active categories of the 13 variables that together define job characteristics, both from the points of view of demand and supply, to a few significant factors. As a result of our analysis, we find two main factors in both countries that explain $86 \%$ of the variance in the case of Spain and $88 \%$ in the case of Argentina. These two factors, or synthetic and significant dimensions of the information, express a similar general pattern of behaviour in both countries that we shall now comment on (see Fig. 3.3).

The first main factor accumulates most of the explanatory power of the information contained in the original variables: $71 \%$ in Spain and $72 \%$ in Argentina, and is a fundamental axis of labour segmentation for both countries with coinciding features relating to the opposition between, on the one hand, the profile of atypical poor quality jobs, i.e. the most insecure due to hiring on a short-term temporary basis, those based on informal labour relations, those worked part-time, involving young male and female workers who have been working for the least time in the company doing the lowest qualified jobs, without supervisory responsibilities and with low levels of education. These are therefore the jobs with the lowest wage levels in the labour market, typical of small, privately owned businesses, especially in the other services, construction and commerce sectors (also in the primary sector in the case of Spain). These jobs are found at the most unstable and devalued polarity of the labour market, where part of the native, youngest and least qualified population is positioned, but above all workers of immigrant origin.

In contrast, there are secure, good quality jobs, typified by indefinite contracts, full-time work and employees that have served the company for the longest. These jobs require medium and high level skills, and therefore include supervisory responsibilities and medium to high levels of education. Consequently, these are jobs with the highest salary levels. They mainly occur in medium and large companies, especially in the public sector, but also in industry and some services: public administration, education, health and transport-community. This is also the case with the financial and professional subsector in Argentina, but less so for Spain as it is at the centre of the graph attracted by the presence of features of the most insecure extreme. In turn, the labour stability that emerges from this polarity of the first dimension corresponds to the oldest segment of the workforce in both countries, as well as a predominance of the native population. 

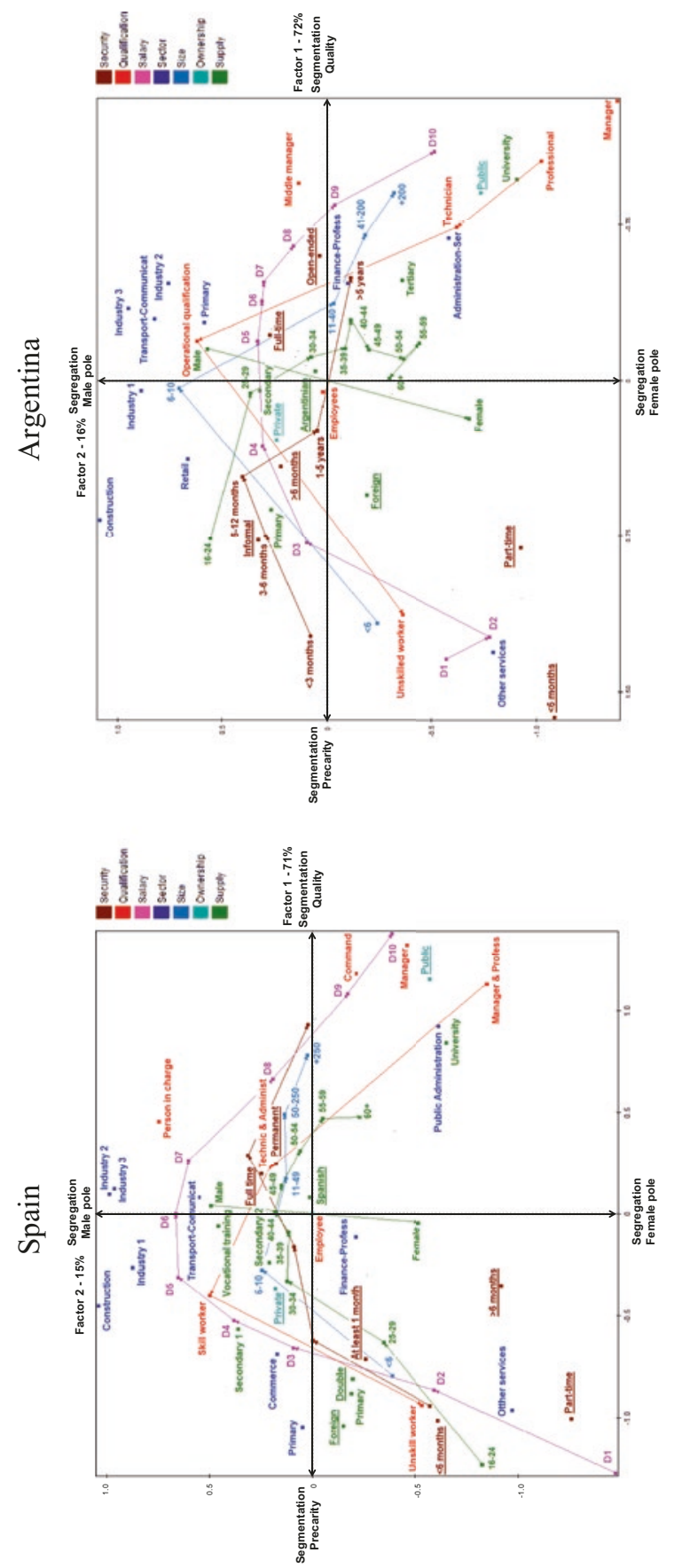

|0 
We thus conclude the configuration of a principal factor of differentiation in the salaried population that we can identify as labour segmentation by contrasting a primary segment with quality, secure, qualified, better paid jobs against a secondary segment that is characterised by insecurity, low qualifications, poor pay and a greater lack of protection.

A second factor, with a much lower weight, of $15 \%$ in the case of Spain and $16 \%$ for Argentina, expands on the first factor to differentiate its intermediate positions from its extremes. This contraposition is shown in the factorial graph by drawing a parabolic point cloud to identify the well-known Guttman effect of correspondence analysis. At one end of the factorial axis we find the intermediate occupational levels of skilled or operational workers, which are particularly characteristic of private industrial, construction and transport industries. These features are shared by both countries, the difference being that in the Spanish case these are stable jobs while in Argentina they can also be informal.

At the other end of the second factorial axis, separate in the first, but occupying the same space from the perspective of the second, for both countries we find both safe and insecure jobs, high and low skill levels, high and low pay, public sector and other services. The confluence in this polarity of the second factor can be explained by its association with the gender variable, which is neutral in the first factor but in this second case expresses labour segregation: at the intermediate pole we mainly find men, with women at the extremes of the poles, i.e. polarised as much at the lowest occupational levels as they are the highest. There is also a notable association between full-time men and part-time women. The particularity of the Spanish case is that the contrast between medium and extreme levels coincides with the age distribution, with a contrast between intermediate ages and the younger and older groups. This contrast is not as clear for Argentina, and where younger and medium ages tend to be associated with the intermediate pole and older people are at the extremes. This opposition between intermediate levels and the remainder also relates to a specific segmentation factor, since it plays a part in establishing the distinction between the profile of the lower primary segment and the rest, and especially against the upper primary segment.

In summary, by means of the factor analysis we conclude that unequal positions are structured in the wage-earning labour market based on two main factors of labour differentiation, both in Spain and Argentina, and which we identify as a first principal axis of segmentation and a secondary one of segregation. We should stress that, using the same labour segmentation indicators in both countries, from the particularity of each social formation, situations of labour inequality arise that coincide in both content and magnitude.

We now use these results to consider how these factors of labour inequality are expressed in terms of groups of male and female workers who share the same profiles in this context, i.e. what job types or segments are configured. To do so, we apply a cluster analysis. 


\subsubsection{Types of Labour Segmentation}

Taking as our classification criteria the two segmentation and segregation factors that emerge from the dimensionalización analysis, we proceed by performing a classification analysis to obtain a typology of labour segments for Spain and Argentina, which we do with four types of labour market stratification and which, as we shall see, enables us to typify social inequalities in the labour market both in dual terms and in the form of a triad of segments. Figure 3.4 shows the distribution of individuals by the typological groups to which they belong in each country. We shall now summarise their main features in the emerging hierarchical order from the lower to the upper segment.

For Spain, the first type clusters 15\% of the cases with the most extreme secondary segment profile that we have called 'lower'. It shares with the following type the low skill levels and job insecurity, and its defining feature is the high concentration of women (78\% of the type) with the lowest level of income (59\% are in decile 1), due in particular to the fact that $80 \%$ of the group work part-time. These are feminised jobs in small private companies, especially other services and financialprofessional. They are generally filled by young people with a low level of education and a high presence of immigrants (17\%).

The second type, with $24 \%$ of all wage-earners, also predominantly features unstable, low-skilled jobs in small private companies, typical of commerce, other services, construction, financial-professional and the primary sector, which is also where the lowest wage levels are, although more tenuously than in the previous case, distributed between deciles 1 to 5 . These are labour relations without seniority in the company, filled by young people with low or secondary levels of education and with a greater presence of women (53\%) and foreigners (15\%).

The third type, with $33 \%$ of salaried workers, covers the characteristic jobs of the lower primary segment, i.e. stable full-time jobs filled by skilled workers and technical-administrative staff in private companies mainly in the industry, construction, commerce and transport-communications sectors, who have worked for some time for their medium or large companies. They receive medium income levels, between deciles 4 and 8 . These places are mainly filled by males (75\%) with secondary and vocational education levels, between 30 and 54 years of age, with a low presence of immigrants.

Finally, the fourth type represents $28 \%$ of wage-earners and is classed as the upper primary segment. It offers the best working conditions: security, high skills, supervisory responsibilities, high salary levels and seniority in the company. These are especially characteristic of large companies and public administration (70\%). These wage earners tend to be the oldest native people, aged 45 years and above, with a greater presence of women $(57 \%)$ and high education levels ( $75 \%$ have university degrees).

For Argentina, the first type represents 14\% of paid work, and as with Spain typically involves unstable jobs with the lowest income. As the lower secondary segment, it brings together low-skilled jobs in the other services sector in small private companies that are filled by women $(90 \%)$, in part-time (70\%), temporary $(59 \%)$ or 

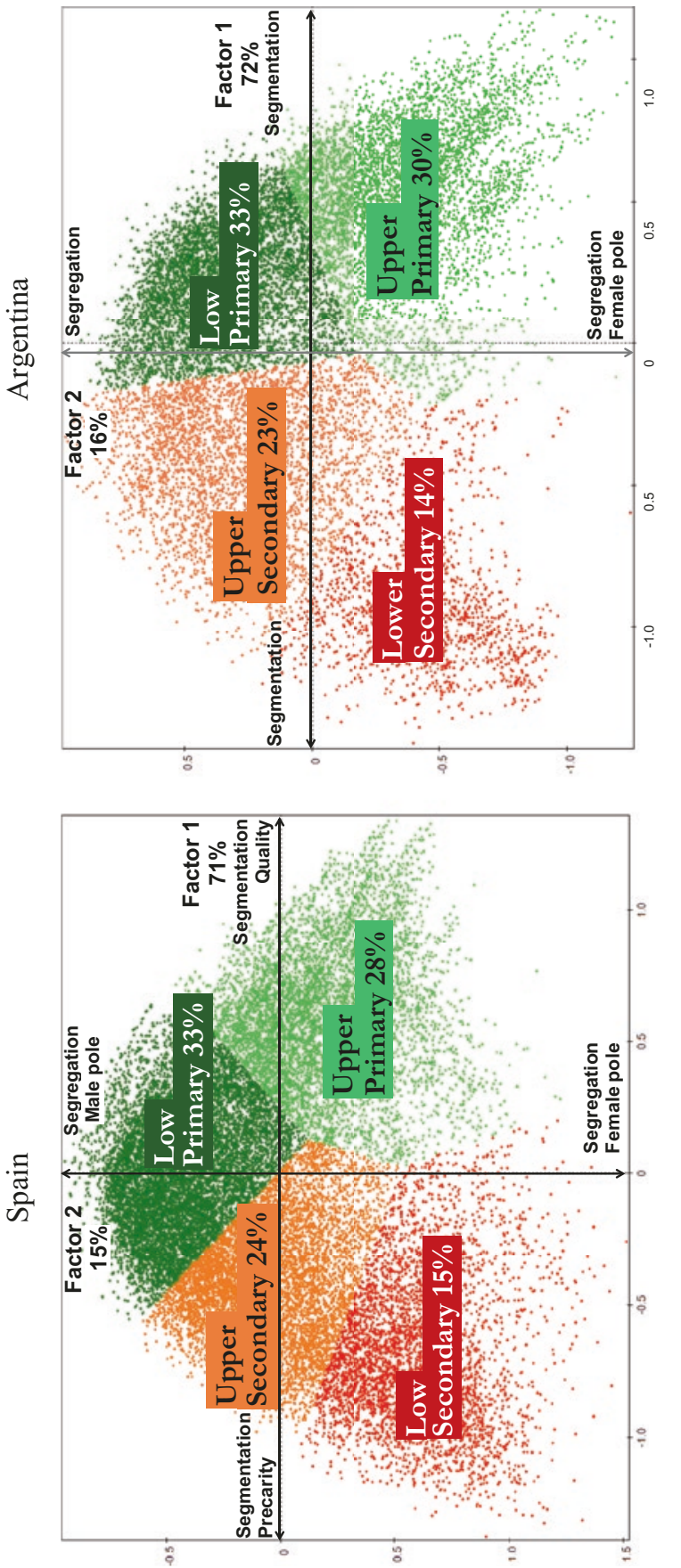

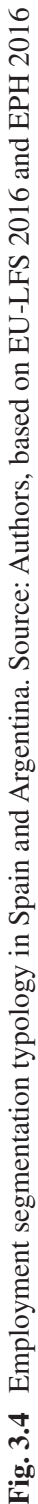


informal (36\%) conditions. Like the same type in Spain, there is a prominent presence of persons of immigrant origin, but it differs in terms of age, for in Argentina this segment is not typically young, but tends to polarise the very young and the very old.

The second type, with $23 \%$ of cases, identifies, as in Spain, the upper secondary segment, with an absolute dominance of insecurity and low skills: 59\% informal labour, $19 \%$ temporary contracts, $42 \%$ unskilled labour and $52 \%$ operational qualification. Correspondingly, they have low salaries that move between deciles 1 and 4. Unlike Spain, there is a predominance of males (68\%) and employment in small, private construction, commerce and also industrial sector 1 companies, in some cases with some seniority in the company. These employees are essentially young people with low levels of education.

The third Argentinian type represents 33\% of salaried workers, and as in Spain is classed as the lower primary segment. It also employs indefinite $(87 \%)$ full-time workers with operational qualifications $(78 \%)$ in private industry 2 and 3, commerce, transport and communications companies, which tend to be medium-sized or large. However, seniority in the company is not a prominent feature as it is in Spain, which is a factor that is distributed similarly across the whole of the salaried population. But it is located in the medium income levels, between deciles 5 and 8 . It is also similarly male dominated $(80 \%)$, with a predominance of secondary education and intermediate ages.

Finally, the fourth type corresponds to the upper primary segment with a weight of $31 \%$. Its profile is similar to its Spanish counterpart in identifying the highest quality jobs: indefinite contracts, specialist or professional skills, the highest income, and the greatest seniority in the company. It also tends to relate to large companies with a predominance of employment in public administration and support services (79\%), together with the financial-professional sector. It also tends to include natives from 35 years of age with an even greater predominance of females than in Spain $(63 \%)$, and with a high level of education. This latter feature differs from Spain in terms of composition, for in Argentina the segment is divided between $38 \%$ with university degrees and $36 \%$ with a terciario (associate's) degree.

These results therefore verify the high degree of similarity between the structures of the Spanish and Argentinian labour markets, with a typology of labour segments that typifies inequalities between paid employment in a similar manner, even in terms of magnitudes. Table 3.3 shows the four types that emerged from our analysis and that we have identified as the primary segment, separating the upper from the lower, and the secondary segment, also distinguishing between upper and lower levels. This division of salaried labour into four types also reveals the segmentation of the labour market in dual terms, grouping the two primary and two secondary segments, or in terms of a triad of categories combining the two secondary types, as shown in the table. These realities have emerged from looking inside each country, considering their own profiles and the relative positions of each labour context. But what is most relevant is the confluence of labour segmentation dynamics in both countries, with the same general features in their results and the emergence of very similar segments that identify and stratify labour inequalities. 
Table 3.3 Distribution of employment segmentation typology for Spain and Argentina according to different number of segments

\begin{tabular}{l|l|l|l|l|l|l|l|l}
\hline $\begin{array}{l}\text { Typology } \\
\text { with 4 } \\
\text { segments }\end{array}$ & $\begin{array}{l}\text { Spain } \\
(\%)\end{array}$ & $\begin{array}{l}\text { Argentina } \\
(\%)\end{array}$ & $\begin{array}{l}\text { Typology } \\
\text { with 3 } \\
\text { segments }\end{array}$ & $\begin{array}{l}\text { Spain } \\
(\%)\end{array}$ & $\begin{array}{l}\text { Argentina } \\
(\%)\end{array}$ & $\begin{array}{l}\text { Typology } \\
\text { with 2 } \\
\text { segments }\end{array}$ & $\begin{array}{l}\text { Spain } \\
(\%)\end{array}$ & $\begin{array}{l}\text { Argentina } \\
(\%)\end{array}$ \\
\hline $\begin{array}{l}\text { Upper } \\
\text { primary }\end{array}$ & 28 & 30 & $\begin{array}{l}\text { Upper } \\
\text { primary }\end{array}$ & 28 & 30 & Primary & 61 & 63 \\
\hline $\begin{array}{l}\text { Lower } \\
\text { primary }\end{array}$ & 33 & 33 & $\begin{array}{l}\text { Lower } \\
\text { primary }\end{array}$ & 33 & 33 & & & \\
\hline $\begin{array}{l}\text { Upper } \\
\text { secondary }\end{array}$ & 24 & 23 & Secondary & 39 & 37 & Secondary & 39 & 37 \\
\hline $\begin{array}{l}\text { Lower } \\
\text { secondary }\end{array}$ & 15 & 14 & & & & & & \\
\hline
\end{tabular}

Source: Authors, based on EU-LFS 2016 and EPH 2016

\subsection{Conclusions}

In the analysis presented herein, we have been able to verify the existence of a common general pattern between the structures of the Spanish and Argentinian labour markets in terms of segmentation, as proposed in our hypothesis. We confirm the configuration of four labour segments, expressible in the form of a triad or dichotomy, and which respond to the profiles described in the segmentationist literature. Thus, two axes are established that divide the wage-earning population. A principal axis of segmentation separates quality employment from instability, a dimension that respectively differentiates the profiles of the primary and secondary segments. A second axis of division introduces us to the segregation of labour by sectors associated with the gender dimension, where male, intermediate skilled, blue collar jobs in industry are contrasted against jobs filled to a greater extent by women, who are polarised between the most highly skilled, white-collar work, especially in the public sector, and unstable, unskilled service work.

The four-segment typology is observed both in Spain and in Argentina with very similar percentile distributions and, above all, described by very similar dominant profiles. In both cases, we have also observed similar labour market structures in terms of both the supply and demand of labour. It is important to note that both Spanish and Argentinian segmentation are the relative expression of the realities in each territory, hence the grouping reflects very similar characteristic traits despite the differing levels of development and social regulation. Their occupational and educational structures do most certainly differ, and informal labour is a particularly distinctive phenomenon in Argentina, and in one case the regulatory social model is uncoordinated and in the other it is semi-coordinated, but despite these different socio-productive contexts, the structures of the inequalities in the labour market share factors of differentiation and there are many common elements to the way labour is stratified in both countries.

These results encourage a more in-depth examination of this phenomenon and should guide future research by extending such case studies to a wider range of 
European and Latin American countries. We appreciate that the hypotheses that have guided our research require further analysis and are subject to later evidence and corroborations that we shall be undertaking in future studies. Indeed, we are already working on a comparative analysis that also incorporates Italy and Chile (Fachelli et al. 2019) where we have been able to corroborate similar results for the four countries. So it will be interesting to ask how far the results achieved thus far are confirmed in a broader comparison of countries, or if, on the contrary, different segmentation models arise. To do so, it will be important to more explicitly incorporate the factors related to the regulatory social model, looking in greater depth at both the comparative institutional elements of labour regulation and labour models, and at the welfare state and association with the social organisation of reproduction. This may produce explanations for unequal living conditions and provide diagnoses that can help to guide public policies.

The labour market is a privileged area of socioeconomic organisation for the study of inequality, especially in the contemporary era, which is so characterised, as we have seen, by such major heterogeneity of labour conditions in comparison with the period of standardisation that was so typical of Fordism and mass manufacture. In our analysis we have focused on the wage-earning population, but the heterogeneity of labour and working conditions would be even more evident even if we were also to consider self-employment or quasi-subordinate work that, especially if skilled, satisfies the need for flexibility in the growing demand for services, in a phase of transition to the tertiary economy, and which is destined to be flooded by the use of digital technologies and become increasingly more global.

Meanwhile, the comparative analysis of the two countries studied, taking into account their differing degrees of economic development and productive structures, levels of informal labour, as well as the different demographic structures and levels of educational of the employed population, seems to confirm the hypothesis of convergence or limited differences in terms of the inequality between the two countries, even though these inequalities are still they expanding, or as strong as ever, within their national contexts. As the data is not longitudinal, nor presented in historical series, we have obviously not been able to assess changing trends, but instead have provided a snapshot of the stratification of labour and jobs from a comparative perspective. Future research will need to introduce a more dynamic perspective in order to analyse changes over time and also in terms of career paths in order to better capture and explain labour segmentation processes. In our static comparative study we have observed a similar segmentation structure in the two countries, which again confirms the theories of labour market dualism, with internal divisions too, interacting with factors both of labour supply and demand that evidence the correspondence between the primary and secondary segments of the labour market and certain socio-biographical characteristics of employees. In fact, our analysis integrates the dimensions of 'inequalities of conditions' and of 'inequalities of opportunities' linked to the characteristics of workers, such as sex, age, level of education and immigrant origin. The evident inequalities in the labour markets of both economies are the result of the categorisation, discrimination and generation of hierarchies of labour that continue to perpetuate in our societies. 
Going back to the questions raised in the introduction, we could say that labour inequalities originate from the types of capitalism and social organisation that are used in the division of productive and reproductive tasks. The similarities found between the two countries therefore transcend the particularities of a given stage of economic development or the structural model of the economy. Naturally, tax, economic and labour policies and the welfare state play a decisive role in correcting and reducing inequalities, as shown in the previous chapter. Segmentation, instability and underemployment are not new phenomena in either country. The persistence of labour segmentation and the consolidation of a large secondary segment, a large number of whom endure poor labour conditions, mean that it is a structural phenomenon. It is a pressing reality that requires major reforms to prevent and eradicate these extreme situations and to create decent work with guarantees of autonomous, non-deprived social life.

The struggle against labour market segmentation is an explicit goal of European Union policy, included in the Treaty on the Functioning of the European Union, and is part of the proclamation of the European Pillar of Social Rights, through which the EU has reaffirmed its commitment to guaranteeing improvements to living and working conditions throughout Europe. The European Union's labour policy establishes the creation of more and better jobs as one of the main targets of its Europe 2020 Strategy. The latest guidelines for 2018, and according to the European Parliament, explicitly state the need for "Better functioning of labour markets (with a specific focus on labour market segmentation)" in the context of the European Employment Strategy, where it also seeks to increase the demand for labour (job creation, labour taxes and wage setting); improve labour supply and skills (including young people and long-term unemployment) and promote equity, combat poverty and foster equal opportunities for all.

The economic crisis and the fact that social and employment policies are mainly the responsibility of national governments have led both to the reproduction and the worsening of inequalities generated in the labour market, mainly marked by policies aimed at flexibilization, the diversity of responses and labour realities throughout the European Union (Eurofund 2019). In the case of Latin America, employment policies are exclusively national and, in general, although they deal with similar problems with their economic and labour structures, they have tended to reduce the inequality with respect to European countries.

Both in one territorial context and the other, an analysis of inequality in the labour market and its expression in terms of segmentation lead us to consider certain general recommendations for public policies. The complexity of the phenomenon of inequality in the labour market requires these public policies to be designed from different fields and perspectives, transcending the strictest scope of employment policies in order to consider both pre-distributive and post-distributive policies, social policies, education policies, gender policies and industrial policies. Thinking in the long term, the ability and willingness to imagine structural reforms with other coordinated policies, public and private investment, and of an economic, social and employment order, has become essential in order to reverse the inefficient and unequal production and labour realities that are persisting over time. Such a change of course must also necessarily contemplate bargaining and agreement processes between social agents. 


\section{Appendix}

Table 3.4 Frequency distribution of employment segmentation variables. 2016 salaried population employed in Spain and Argentina

\begin{tabular}{|c|c|c|c|c|c|c|}
\hline \multirow[b]{2}{*}{ Dimension } & \multicolumn{3}{|l|}{ Spain } & \multicolumn{3}{|l|}{ Argentina } \\
\hline & Variables & Frequency & $\%$ & Variables & Frequency & $\%$ \\
\hline \multicolumn{7}{|c|}{ Demand variables } \\
\hline \multirow[t]{18}{*}{ 1. Security } & \multicolumn{6}{|c|}{ Type of contract and duration } \\
\hline & Open-ended & 22,472 & 75.6 & Open-ended & 10,885 & 61.2 \\
\hline & At least 1 month & 2957 & 9.9 & - & & \\
\hline & $<6$ months & 2580 & 8.7 & $<6$ months & 1788 & 10.1 \\
\hline & $>6$ months & 1714 & 5.8 & $>6$ months & 888 & 5.0 \\
\hline & - & & & $\begin{array}{l}\text { Informal } \\
\text { employment }\end{array}$ & 4226 & 23.8 \\
\hline & No data ${ }^{1}$ & (314) & - & No data $^{1}$ & (9) & - \\
\hline & \multicolumn{6}{|c|}{ Seniority in the company } \\
\hline & $<1$ year & 5260 & 17.5 & $<3$ months & 1394 & 7.9 \\
\hline & $2-3$ years & 3773 & 12.6 & 3-6 months & 782 & 4.4 \\
\hline & $4-10$ years & 7080 & 23.6 & 6-12 months & 890 & 5.1 \\
\hline & $11-20$ years & 7171 & 23.9 & $1-5$ years & 6013 & 34.1 \\
\hline & +20 years & 6753 & 22.5 & $>5$ years & 8542 & 48.5 \\
\hline & & & & No data ${ }^{1}$ & $(176)$ & - \\
\hline & \multicolumn{6}{|l|}{ Type of workday } \\
\hline & Full-time & 25,082 & 83.5 & Full-time & 13,378 & 77.8 \\
\hline & Part-time & 4955 & 16.5 & Part-time & 3817 & 22.2 \\
\hline & & & & No data & (603) & - \\
\hline \multirow[t]{12}{*}{ 2. Qualification } & \multicolumn{6}{|l|}{ Occupation } \\
\hline & $\begin{array}{l}\text { Manager \& } \\
\text { Professional }\end{array}$ & 6282 & 21.0 & Professional & 1506 & 8.5 \\
\hline & $\begin{array}{l}\text { Technician \& } \\
\text { Administrative }\end{array}$ & 6998 & 23.4 & Technician & 3089 & 17.4 \\
\hline & Skill worker & 12,343 & 41.4 & $\begin{array}{l}\text { Operational } \\
\text { qualification }\end{array}$ & 8358 & 47.0 \\
\hline & Unskill worker & 4226 & 14.2 & Unskill worker & 4845 & 27.2 \\
\hline & No data $^{1}$ & (188) & - & No data $^{1}$ & (134) & - \\
\hline & \multicolumn{6}{|l|}{ Supervision } \\
\hline & Employee & 25,121 & 84.5 & Employee & 16,865 & 95.3 \\
\hline & Person in charge & 1912 & 6.4 & - & & \\
\hline & Middle manager & 2113 & 7.1 & Middle manager & 536 & 3.0 \\
\hline & Manager & 584 & 2.0 & Manager & 296 & 1.7 \\
\hline & No data ${ }^{1}$ & (307) & - & No data ${ }^{1}$ & (53) & - \\
\hline
\end{tabular}


Table 3.4 (continued)

\begin{tabular}{|c|c|c|c|c|c|c|}
\hline \multirow[b]{2}{*}{ Dimension } & \multicolumn{3}{|l|}{ Spain } & \multicolumn{3}{|l|}{ Argentina } \\
\hline & Variables & Frequency & $\%$ & Variables & Frequency & $\%$ \\
\hline \multirow[t]{12}{*}{ 3. Salary } & \multicolumn{6}{|l|}{ Salary deciles } \\
\hline & Decile 1 & 2949 & 9.8 & Decile 1 & 1632 & 9.2 \\
\hline & Decile 2 & 2832 & 9.4 & Decile 2 & 1285 & 7.2 \\
\hline & Decile 3 & 2904 & 9.7 & Decile 3 & 1371 & 7.7 \\
\hline & Decile 4 & 3017 & 10.0 & Decile 4 & 1585 & 8.9 \\
\hline & Decile 5 & 2906 & 9.7 & Decile 5 & 1984 & 11.1 \\
\hline & Decile 6 & 3086 & 10.3 & Decile 6 & 1454 & 8.2 \\
\hline & Decile 7 & 2991 & 10.0 & Decile 7 & 471 & 2.6 \\
\hline & Decile 8 & 3074 & 10.2 & Decile 8 & 1735 & 9.7 \\
\hline & Decile 9 & 3163 & 10.5 & Decile 9 & 1299 & 7.3 \\
\hline & Decile 10 & 3115 & 10.4 & Decile 10 & 1316 & 7.4 \\
\hline & & & & No data & 3668 & 20.6 \\
\hline \multirow{23}{*}{$\begin{array}{l}4 . \\
\text { Characterization } \\
\text { of the company }\end{array}$} & \multicolumn{6}{|l|}{ Activity sector } \\
\hline & Primary & 809 & 2.7 & Primary & 185 & 1.1 \\
\hline & Industry 1 & 1494 & 5.0 & Industry 1 & 1088 & 6.2 \\
\hline & Industry 2 & 1895 & 6.3 & Industry 2 & 393 & 2.2 \\
\hline & Industry 3 & 1380 & 4.6 & Industry 3 & 806 & 4.6 \\
\hline & Construction & 1454 & 4.8 & Construction & 1170 & 6.7 \\
\hline & Retail & 6302 & 21.0 & Retail & 2274 & 13.0 \\
\hline & $\begin{array}{l}\text { Transport- } \\
\text { Communications }\end{array}$ & 2129 & 7.1 & $\begin{array}{l}\text { Transport- } \\
\text { Communications }\end{array}$ & 1387 & 7.9 \\
\hline & $\begin{array}{l}\text { Finance- } \\
\text { Professionals }\end{array}$ & 3536 & 11.8 & $\begin{array}{l}\text { Finance- } \\
\text { Professionals }\end{array}$ & 1003 & 5.7 \\
\hline & $\begin{array}{l}\text { Public } \\
\text { Administration }\end{array}$ & 8872 & 29.5 & Administration-Ser & 6163 & 35.2 \\
\hline & Other services & 2166 & 7.2 & Other services & 3040 & 17.4 \\
\hline & & & & No data ${ }^{1}$ & $(245)$ & - \\
\hline & \multicolumn{6}{|c|}{ Ownership of the company } \\
\hline & Public & 7199 & 24.0 & Public & 4348 & 24.4 \\
\hline & Private & 22,838 & 76.0 & Private & 13,450 & 75.6 \\
\hline & & & & No data ${ }^{1}$ & $(240)$ & - \\
\hline & \multicolumn{6}{|l|}{ Company size } \\
\hline & $<6$ workers & 5270 & 17.5 & $<6$ workers & 4767 & 26.8 \\
\hline & $6-10$ & 2132 & 7.1 & $6-10$ & 1679 & 9.4 \\
\hline & $11-49$ & 6757 & 22.5 & $11-40$ & 2684 & 15.1 \\
\hline & $50-250$ & 5014 & 16.7 & $41-200$ & 2255 & 12.7 \\
\hline & $>250$ & 4428 & 14.7 & $>200$ & 2632 & 14.8 \\
\hline & No data & 6436 & 21.4 & No data & 3782 & 21.3 \\
\hline
\end{tabular}


Table 3.4 (continued)

\begin{tabular}{|c|c|c|c|c|c|c|}
\hline \multirow[b]{2}{*}{ Dimension } & \multicolumn{3}{|l|}{ Spain } & \multicolumn{3}{|l|}{ Argentina } \\
\hline & Variables & Frequency & $\%$ & Variables & Frequency & $\%$ \\
\hline \multicolumn{7}{|l|}{ Supply variables } \\
\hline \multirow[t]{3}{*}{ 5. Gender } & \multicolumn{6}{|l|}{ Sex } \\
\hline & Male & 15,383 & 51.2 & Male & 9707 & 54.5 \\
\hline & Female & 14,654 & 48.8 & Female & 8091 & 45.5 \\
\hline \multirow[t]{10}{*}{ 6. Age } & \multicolumn{6}{|l|}{ Age } \\
\hline & $16-24$ years & 1456 & 4.8 & 16-24 years & 2380 & 13.4 \\
\hline & $25-29$ years & 2388 & 8.0 & $25-29$ years & 2404 & 13.5 \\
\hline & 30-34 years & 2959 & 9.9 & 30-34 years & 2285 & 12.8 \\
\hline & $35-39$ years & 4251 & 14.2 & $35-39$ years & 2497 & 14.0 \\
\hline & 40-44 years & 4662 & 15.5 & 40-44 years & 2202 & 12.4 \\
\hline & $45-49$ years & 4491 & 15.0 & 45-49 years & 1813 & 10.2 \\
\hline & $50-54$ years & 4385 & 14.6 & $50-54$ years & 1624 & 9.1 \\
\hline & $55-59$ years & 3569 & 11.9 & $55-59$ years & 1241 & 7.0 \\
\hline & $60+$ & 1876 & 6.2 & $60+$ & 1351 & 7.6 \\
\hline \multirow[t]{5}{*}{ 7. Immigration } & \multicolumn{6}{|l|}{ Nationality } \\
\hline & Spanish & 27,700 & 92.2 & Argentinian local & 14,482 & 81.4 \\
\hline & Double nationality & 709 & 2.4 & $\begin{array}{l}\text { Argentinian } \\
\text { province }\end{array}$ & 2400 & 13.5 \\
\hline & Foreign & 1628 & 5.4 & Foreign & 909 & 5.1 \\
\hline & & & & No data $^{1}$ & (6) & - \\
\hline \multirow[t]{6}{*}{ 8. Education } & \multicolumn{6}{|l|}{ Educational level } \\
\hline & Primary & 1448 & 4.8 & Primary & 5942 & 33.5 \\
\hline & $\begin{array}{l}\text { Secondary first } \\
\text { stage }\end{array}$ & 8124 & 27.0 & Secondary & 5894 & 33.2 \\
\hline & $\begin{array}{l}\text { Secondary second } \\
\text { stage }\end{array}$ & 7027 & 23.4 & Tertiary & 3510 & 19.8 \\
\hline & Vocational training & 4187 & 13.9 & University & 2394 & 13.5 \\
\hline & University & 9251 & 30.8 & No data ${ }^{1}$ & $(59)$ & - \\
\hline Total & & 30,037 & 100 & & 17,798 & 100 \\
\hline
\end{tabular}


Table 3.4 (continued)

\begin{tabular}{|c|c|c|c|c|c|}
\hline \multirow[b]{2}{*}{ Dimension } & \multicolumn{2}{|l|}{ Spain } & \multicolumn{3}{|l|}{ Argentina } \\
\hline & Variables & Frequency $\%$ & Variables & Frequency & \\
\hline & \multicolumn{2}{|c|}{$\begin{array}{l}\text { Source: INE, EU-LFS, annual data } \\
\text { for } 2016 . \\
\text { 1. Categories treated as illustrative } \\
\text { with random assignment by low } \\
\text { frequency ( } 1.9 \% \text { or less). After } \\
\text { cleaning, of the } 74 \text { categories, } 66 \text { are } \\
\text { considered active. } \\
\text { 2. The grouping of sectors can be } \\
\text { consulted in the EU-LFS } \\
\text { methodological information. In } \\
\text { particular, Industry } 1 \text { is: food, } \\
\text { textiles, leather, wood and paper; } \\
\text { Industry 2: extractive, petroleum } \\
\text { refining, chemical, pharmaceutical, } \\
\text { rubber and plastics industry, and } \\
\text { Industry 3: construction of } \\
\text { machinery, electrical equipment and } \\
\text { transport equipment. Industrial } \\
\text { installation and repair. }\end{array}$} & \multicolumn{3}{|c|}{$\begin{array}{l}\text { Source: INDEC. Encuesta } \\
\text { Permanente de Hogares, second } \\
\text { quarter of } 2016 . \\
\text { 1. Categories treated as illustrative } \\
\text { with random assignment by low } \\
\text { frequency (1\% or less). After } \\
\text { cleaning, of the } 74 \text { categories } 65 \text { are } \\
\text { considered active. } \\
\text { 2. The grouping was carried out } \\
\text { based on CAES } 1.0 \text {. It was } \\
\text { homogenized with the classification } \\
\text { of Spain and the different items are } \\
\text { marked below: Industry 1: idem } \\
\text { Spain. Industry 2: Idem Spain + } \\
\text { Glass. Industry 3: Idem Spain + } \\
\text { Metal Fab. Fab. Gas, electricity and } \\
\text { steam. Administration: Public Adm. } \\
\text { And Support Services. Other } \\
\text { services: Water, sewage and waste } \\
\text { management; Accommodation and } \\
\text { catering services; Domestic } \\
\text { Employers. } \\
\text { 3. Amount for salaries/wages, family } \\
\text { salary, overtime, other bonuses and } \\
\text { tickets. }\end{array}$} \\
\hline
\end{tabular}

\section{References}

Alós-Moner, R., Beneyto, P. J., \& Jódar, P. (2017). Reforma laboral y desregulación del mercado de trabajo. Anuario IET de Trabajo y Relaciones Laborales, 5, 73-86. Retrieved from http:// revistes.uab.cat/anuarioiet/article/view/v4-alos-beneyto-jodar/55-pdf-es.

Alós-Moner, R. (2008). Segmentación de los mercados de trabajo y relaciones laborales. El sindicalismo ante la acción colectiva. Cuadernos de Relaciones Laborales, 26(1), 123-148.

Arntz, M., Gregory, T. \& Zierahn, U. (2016). The risk of automation for jobs in OECD countries: A comparative analysis. OECD Social, Employment and Migration Working Papers, 189. doi:https://doi.org/10.1787/5jlz9h56dvq7-en.

Atkinson, A. B. (2015). Inequality: What can be done? Cambridge: Harvard University Press.

Banyuls, J., \& Recio, A. (2017). Labour segmentation and precariousness in Spain: Theories and evidence. In D. Grimshaw, C. Fagan, G. Hebson, \& I. Tavora (Eds.), Making work more equal: A new labour segmentation approach (pp. 129-149). Manchester: Manchester University Press. Retrieved from http://www.oapen.org/search?identifier=634747.

Banyuls, J., Miguélez, F., Recio, A., Cano, E., \& Lorente, R. (2009). The transformation of the employment system in Spain: Towards a mediterranean neoliberalism? In G. Bosch, S. Lehndorff, \& J. Rubery (Eds.), European employment models in flux. A comparison of institutional change in nine European countries (pp. 247-269). Basingstoke: Palgrave Macmillan.

Beck, U., \& Beck-Gernsheim, E. (2001). Individualization. Institutionalized individualism and its social and political consequences. London: Sage. 
Bertranou, F., \& Casanova, L. (Coord.) (2015). Caminos hacia la formalización laboral en Argentina. Buenos Aires: Oficina Internacional del Trabajo.

Bertranou, F., Casanova, L., Jiménez, M., \& Jiménez, M. (2013). Informality and employment quality in Argentina: Country case study on labour market segmentation. Geneva: International Labour Office. https://doi.org/10.2139/ssrn.2350292.

Bettio, F., \& Plantenga, J. (2004). Comparing care regimes in Europe. Feminist Economics, $10(1), 85-113$.

Bettio, F., \& Verashchagina, A. (2009) Gender segregation in the labour market: Root causes, implications and policy responses in the EU. EU Expert Group on Gender and Employment (EGGE). Luxembourg: European Commission.

Borrás, V., Carrasquer, P., Moreno, S., \& Torns, T. (2012). Trayetorias laborales y de vida. Una aproximación al modelo de empleo español. Inguruak: Revista vasca de sociología y ciencia política, 51-52, 131-146.

Bosch, G., Lendorff, S., \& Rubery, J. (Eds.). (2009). European employment models in flux: A comparison of institutional change in nine European countries. New York: Palgrave Macmillan.

Burroni, L. (2016). Capitalismi a confronto. Milano: Il Mulino.

Caïs, J. (1997). Metodología del análisis comparativo. Madrid: Centro de Investigaciones Sociológicas.

Carrasquer, P., \& Amaral, M. (2019). El terra enganxós de les dones a la ciutat de Barcelona. Barcelona: Ajuntament de Barcelona-Barcelona Activa.

Carrasquer, P., Recio,C. \& Rodríguez-Soler, J. (2015). Políticas de igualdad y modelos de empleo: el caso español. Revista del Ministerio de Empleo y Seguridad Social, 106, 75-103.

Castells, M. (2000). The information age: economy, society and culture. Vol. 1, The rise of network society. Oxford: Blackwell.

Cebrián, I., Moreno, G., \& Pérez, J. I. (2013). Las reformas laborales en la obra de Luis Toharia. Revista de Economía Laboral, 10, 18-47.

CEPAL (Comisión Económica para América Latina y el Caribe). (2012). Eslabones de desigualdad. Heterogeneidad estructural, empleo y protección social. Santiago de Chile: CEPAL. Retrieved from https://repositorio.cepal.org/bitstream/handle/11362/27973/S1200141_es.pdf?sequence= 1\&isAllowed=y.

Coatz, D., Sarabia, M., \& Carregal, C. (2015). Sobre sinergias y virtudes del cambio estructural para el desarrollo en Argentina. In F. Bertranou, C. Carregal, L. Casanova, D. Coatz, \& M. Sarabia (Eds.), Un enfoque productivo para el trabajo decente. Desarrollo industrial, entramado institucional y empleo de calidad en Argentina. Buenos Aires: Oficina Internacional del Trabajo.

Craig, C., Rubery, J., Tarling, R., \& Wilkinson, F. (1982). Labour market structure, industrial organisation and low pay. Cambridge: Cambridge University Press.

Crouch, C. (2014). Post-democracy. Malden, MA: Polity.

De Miguel, M., \& Woyecheszen, S. (2015). Estructura productiva e informalidad laboral. En F. Bertranou y L. Casanova (Coord.). Caminos hacia la formalización laboral en Argentina. Buenos Aires: Oficina Internacional del Trabajo.

Del Pino, E., \& Rubio, J. (2016). Los Estados del Bienestar en la encrucijada. Madrid: Tecnos.

Doellgast, V., Lillie, N., \& Pulignano, V. (Eds.). (2018). Reconstructing solidarity: Labor unions, precarious work and the politics of institutional change in Europe. Oxford: Oxford University Press.

Doeringer, P. \& Piore, M. (1971). Internal Labor Markets and Manpower Analysis. Lexington, MA: Heath.

Dubet, F. (2010). Integrazione, coesione e disuguaglianze sociali. Stato e mercato, 88(1), 33-58.

Esping-Andersen, G. (2000). Fundamentos sociales de las economías postindustriales. Barcelona: Ariel.

Eurofund. (2019). Labour market segmentation: Piloting new empirical and policy analyses. Luxembourg: Publications Office of the European Union. Retrieved from https:// www.eurofound.europa.eu/publications/report/2019/1abour-market-segmentationpiloting-new-empirical-and-policy-analyses. 
Fachelli, S., Semenza, R., Sarti, S., \& López-Roldán, P. (2019). Análisis comparativo de la segmentación del mercado de trabajo en España, Italia, Argentina y Chile. XIII Congreso Español de Sociología. Valencia: Federación Española de Sociología.

Fina, L., \& Toharia, L. (1987). Las causas del paro en España: Un punto de vista estructural. Madrid: Fundación Instituto de Estudios Sociales Avanzados.

Frey, C. B., \& Osborne, M. A. (2017). The future of employment: How susceptible are jobs to computerization? Technological Forecasting and Social Change, 114(C), 254-280. https://doi. org/10.1016/j.techfore.2016.08.019.

Gereffi, G., Humphrey, J., \& Sturgeon, T. (2005). The Governance of Global Value chain. Review of International Political Economy, 12(1), 78-104. https://doi.org/10.1080/09692290500049805.

Gibert, F. (2011). El mercat de treball metall-mecànic a Catalunya. Una anàlisi des de l'Enfocament Segmentacionista de Cambridge per al cas de la comarca d'Osona. Bellaterra: Universitat Autònoma de Barcelona. Retrieved from https://www.tdx.cat/handle/10803/42290\#page=1.

González Gago, E., \& Segales Kirzner, M. (2014). Women, gender equality and the economic crisis in Spain. In J. Rubery \& M. Karamessini (Eds.), Women and austerity: The economic crisis and the future for gender equality (pp. 228-247). Oxon: Routledge.

Gordon, D., Edwards, R., \& Reich, M. (1982). Segmented work, divided workers: The historical transformation of work in the United States. Cambridge: Cambridge University Press.

Granovetter, M., \& Tilly, C. (1988). Inequality in the labor processes. In N. Smelser (Ed.), Handbook of sociology (pp. 175-221). Newbury Park: Sage.

Grimshaw, D., \& Rubery, J. (2005). Inter-capital relations and network organisation: redefining the work and employment nexus. Cambridge Journal of Economics, 29, 1027-1051.

Grimshaw, D., Fagan, C., Hebson, G., \& Tavora, I. (Eds.). (2017). Making work more equal: A new labour segmentation approach. Manchester: Manchester University Press.

Hall, P. A., \& Soskice, D. (2001). Varieties of capitalism: The institutional foundations of comparative advantage. New York: Oxford University Press.

Heckman, J., \& Pagés, C. (2005). Regulación y empleo: Lecciones de América Latina y el Caribe. Santiago de Chile: CIEDESS.

Heidenreich, M. (2016). Introduction: the double dualization of inequality in Europe. In M. Heidenreich (Ed.), Exploring inequality in Europe. Diverging income and employment opportunities in the crisis. Cheltenham: Edward Elgar.

Holt, R. T., \& Turner, J. E. (1970). The methodology of comparative research. New York: The Free Press.

Humphries, J., \& Rubery, J. (1984). The reconstruction of the supply side of the labour market: The relative autonomy of social reproduction. Cambridge Journal of Economics, 8(4), 331-346.

ILO. (2016). Key indicators of the labour market (9th ed.). Geneva: International Labour Office. Retrieved from https://www.ilo.org/global/statistics-and-databases/research-and-databases/ kilm/WCMS_498929/lang\%2D\%2Den/index.htm

ILO. (2019). Perspectivas sociales y del empleo en el mundo: Tendencias 2019. Geneva: International Labour Organization. Retrieved from https://www.ilo.org/wcmsp5/groups/ public/\%2D $\% 2 \mathrm{D}$-dgreports/\%2D $\% 2 \mathrm{D}$-dcomm/\%2D\%2D-publ/documents/publication/ wcms_670542.pdf

Kalleberg, A. (2009). Precarious work, insecure workers: Employment relations in transition. American Sociological Review, 74(1), 1-22. https://doi.org/10.1177/000312240907400101.

Kushi, S., \& McManus, I. P. (2018). Costos diferenciados de la austeridad según el género: Efectos del régimen de bienestar y de las políticas de empleo en países de la OCDE, 2000-2013. Revista Internacional del Trabajo, 137(4), 609-640.

Lanari, M. E. (2015). Argentina: Las implicaciones de las políticas públicas y la regulación laboral sobre el trabajo 2008-2013. Cuadernos del CENDES, 32(89), 1-16.

Lebart, L., Morineau, A., \& Piron, M. (1997). Statistique exploratoire multidimensionnelle. Paris: Dunod.

López-Roldán, P. (1996a). La construcción de tipologías: Metodología de análisis. Papers. Revista de Sociologia, 48, 9-29. https://doi.org/10.5565/rev/papers.1811. 
López-Roldán, P. (1996b). La construcción de una tipología de segmentación del mercado de trabajo. Papers. Revista de Sociologia, 48, 41-58. https://doi.org/10.5565/rev/papers.1812.

López-Roldán, P., \& Fachelli, S. (2015). Metodología de la Investigación Social Cuantitativa. Bellaterra (Cerdanyola del Vallès): Dipòsit Digital de Documents. Barcelona: Universitat Autònoma de. Retrieved from http://ddd.uab.cat/record/129382.

López-Roldán, P., \& Fachelli, S. (2019). Segmentación del empleo y apreciación de la educación en un modelo productivo anclado. Análisis comparativo entre España y Argentina. Papers. Revista de Sociologia, 104(2), 159-202. https://doi.org/10.5565/rev/papers.2571.

Marshall, A. (2004). Labour market policies and regulations in Argentina, Brazil and Mexico: Programmes and impacts. Employment Strategy Paper, 2004(13). Geneva: International Labour Organization. Retrieved from https://www.ilo.org/empelm/pubs/WCMS_114302/ lang\%2D\%2Den/index.htm

Martín Artiles, A., Lope, A., Barrientos, D., \& Moles, B. (2017). Adecuación y demanda de formación en la empresa. La inencontrable adecuación entre formación y empleo. Anuario IET de Trabajo y Relaciones Laborales, 5, 113-134. Retrieved from http://revistes.uab.cat/anuarioiet/ article/view/v4-martin-lope-barrientos-moles/58-pdf-es.

Martín Artiles, A., Lope, A., Barrientos Sánchez, D. \& Moles Kalt, B. (2018). Learning to Work: Trajectories and Discourses. Revista Española de Investigaciones Sociológicas, 164, 115-134. (http://dx.doi.org/10.5477/cis/reis.164.115)

Martín-Artiles, A. (2008). ¿Modelo social de bajo coste? Arxius de Sociologia, 18, 9-24.

Menz, G. (2008). Varieties of capitalism and Europeanization. National response strategies to the single European market. New York: Oxford University Press.

Miguélez, F. (2004). La flexibilidad laboral. Trabajo, 13, 17-36.

Miguélez, F., \& López-Roldán, P. (Coord.) (2014). Crisis, empleo e inmigración en España. Un análisis de las trayectorias laborales. Bellaterra (Barcelona): Universitat Autònoma de Barcelona.

Molina, O., \& Miguélez, F. (2016). Post-crisis social dialogue in Spain: The calm after the storm. Geneva: International Labour Office.

MTEySS (Ministerio de Trabajo, Empleo y Seguridad Social). (2009). Boletín Estadístico de la Seguridad Social. Buenos Aires: MTEySS.

Neffa, J. C. (2008). Las teorías de la segmentación de los mercados de trabajo. In F. EymardDuvernay \& J. C. Neffa (Eds.), Teorías económicas sobre el mercado de trabajo. III. Análisis institucionalistas. Buenos Aires: Fondo de Cultura Económica-CEIL-PIETTE.OIT-PREALC.

Palomino, H., \& Trajtemberg, D. (2007). Una nueva dinámica de las relaciones laborales y la negociación colectiva en la Argentina. Revista de Trabajo, 2(3), 47-68.

Panigo, D., \& Neffa, J. C. (2009). El mercado de trabajo argentino en el nuevo modelo de desarrollo. Buenos Aires: Dirección Nacional de Programación Macroeconómica.

Parsons, T. (1951). The social system. London: Routledge and Kegan Paul.

Pelling, L. (2019, January 17). The Swedish face of inequality. Social Europe. Retrieved from https://www.socialeurope.eu/the-swedish-face-of-inequality

Piketty, T. (2013). Le capital au XXI siècle. Paris: Seuil.

Pinto, A. (1970). Naturaleza e implicaciones de la heterogeneidad estructural de América Latina. El trimestre económico, 37(145), 83-100.

Poy, S. (2017). Heterogeneidad de la estructura ocupacional y segmentación del mercado de trabajo. Gran Buenos Aires, 1974-2014. Trabajo y Sociedad, 29, 353-376. Retrieved from http:// www.unse.edu.ar/trabajoysociedad/29\%20POY\%20SANTIAGO $\% 20$ Heterogeneidad $\% 20$ estructural_distribucion\%20del\%20ingreso.pdf.

PREALC (Programa Regional de Empleo para América Latina y el Caribe). (1978). Sector Informal. Funcionamiento y Políticas. Santiago de Chile: OIT.

Prebisch, R. (1949). El desarrollo económico de América Latina y algunos de sus principales problemas. Santiago de Chile: Naciones Unidas.

Prieto, C. (2002). La degradación del empleo o la norma social del empleo flexibilizado. Sistema, $168,89-106$. 
Ramos Pinto, P. (2016, September 20). The inequality debate: Why now, why like this? Items, Insights from the Social Sciences. Retrieved from https://items.ssrc.org/what-is-inequality/ the-inequality-debate-why-now-why-like-this/

Recio, A. (1991). La segmentación del mercado laboral en España. In F. Miguélez \& C. Prieto (Eds.), Las relaciones laborales en España (pp. 97-115). Madrid: Siglo XXI.

Rubery, J. (1978). Structured labour markets, worker organization and low pay. Cambridge Journal of Economics, 2(1), 17-37.

Rubery, J. (2005). The shaping of work and working time in the service sector. In G. Bosch \& S. Lehndorff (Eds.), Working in the service sector. A tale from different worlds. London: Routledge.

Rubery, J. (2007). Developing segmentation theory: A thirty year perspective. Économies et Sociétés, 28(6), 941-964.

Rubery, J. (2014). From 'women and recession' to 'women and austerity': A framework for analysis. In M. Karamessini \& J. Rubery (Eds.), Women and austerity (pp. 17-36). Croydon: Routledge.

Salvia, A. (2012). La Trampa Neoliberal. Nueva Marginalidad, Desigualdad Económica y Reformas Estructurales en la Argentina: 1990-2003. Buenos Aires: EUDEBA.

Salvia, A. (2014). Un régimen consolidado de bienestar con desigualdades sociales persistentes. Claroscuros en el desarrollo humano y la integración social (2010-2013). Barómetro de la Deuda Social Argentina. Serie del Bicentenario/Año 4. Buenos Aires: Universidad Católica Argentina.

Salvia, A., \& Rubio, M. B. (2019). Tendencias sobre la desigualdad. Aportes para pensar la Argentina actual. Ciudad Autónoma de Buenos Aires: Colección IIGG-CLACSO.

Salvia, A., Poy, S., \& Vera, J. (2018). Políticas sociales, pobreza y bienestar. Argentina: análisis comparado de distintos regímenes socioeconómicos (1992-2012). In F. Cortés (Coord.), Temas de Política Social de México y América Latina. Ciudad de México: El Colegio de México y Universidad Nacional Autónoma de México.

Sánchez-Mira, N., \& O'Reilly, J. (2018). Household employment and the crisis in Europe. Work, Employment and Society, 33(3), 422-443.

Semenza, R., \& Pichault, M. (2019). The challenges of self-employment in Europe. Status, social protection and collective representation. Cheltenham: Edward Elgar.

Simonazzi, A. (2009). Care regimes and national employment models. Cambridge Journal of Economics, 33(2), 211-232.

Standing, G. (2011). The precariat: The new dangerous class. London: Bloomsbury Academic.

Toharia, L. (2011). El debate sobre las reformas necesarias para la economía española: el mercado de trabajo. Gaceta Sindical, 17, 201-236.

Tomada, C. (2014). La trayectoria de una política laboral para la inclusión. Revista de Trabajo, 10(12), 73-80.

Torns, T., Carrasquer, P., Moreno, S., \& Borrás, V. (2013). Career paths in Spain: Gendered division of labour and informal employment. Revue Interventions Économiques, 47, 1-14. https:// doi.org/10.4000/interventionseconomiques.1935.

Vaughan-Whitehead, D. (Ed.) (2015). The European social model in crisis: Is Europe losing its soul? Cheltenham: Edward Elgar and Geneva: International Labour Organization.

Verd, J. M., \& López-Andreu, M. (2016). Crisis del empleo y polarización de las trayectorias laborales. El caso de los adultos jóvenes en Cataluña. Papers. Revista de Sociologia, 101(1), 5-30. https://doi.org/10.5565/rev/papers.2167.

Wilkinson, F. (Ed.). (1981). The dynamics of labor market segmentation. London: Academic. 
Open Access This chapter is licensed under the terms of the Creative Commons Attribution 4.0 International License (http://creativecommons.org/licenses/by/4.0/), which permits use, sharing, adaptation, distribution and reproduction in any medium or format, as long as you give appropriate credit to the original author(s) and the source, provide a link to the Creative Commons licence and indicate if changes were made.

The images or other third party material in this chapter are included in the chapter's Creative Commons licence, unless indicated otherwise in a credit line to the material. If material is not included in the chapter's Creative Commons licence and your intended use is not permitted by statutory regulation or exceeds the permitted use, you will need to obtain permission directly from the copyright holder. 